\title{
Review \\ Cyanobacteria, Cyanotoxins, and Neurodegenerative Diseases: Dangerous Liaisons
}

\author{
Paola Sini $\left.{ }^{1}{ }^{(}\right)$, Thi Bang Chau Dang ${ }^{1,2}$, Milena Fais ${ }^{1}{ }^{\circledR}$, Manuela Galioto ${ }^{1}$, Bachisio Mario Padedda ${ }^{3} \mathbb{C}$, \\ Antonella Lugliè ${ }^{3}(\mathbb{D})$, Ciro Iaccarino ${ }^{1}(\mathbb{D})$ and Claudia Crosio ${ }^{1, *}(\mathbb{D})$ \\ 1 Department of Biomedical Sciences, University of Sassari, 07100 Sassari, Italy; \\ sinipaoladrop@gmail.com (P.S.); bangchauykt@gmail.com (T.B.C.D.); faismilena@gmail.com (M.F.); \\ galioto@uniss.it (M.G.); ciaccarino@uniss.it (C.I.) \\ 2 Department of Biochemistry, Hue University, Hue City 7474, Vietnam \\ 3 Laboratory of Aquatic Ecology, Department of Architecture, Design and Urban Planning, University of \\ Sassari, 07100 Sassari, Italy; bmpadedda@uniss.it (B.M.P.); luglie@uniss.it (A.L.) \\ * Correspondence: ccrosio@uniss.it; Tel.: +39-079228653
}

check for updates

Citation: Sini, P.; Dang, T.B.C.; Fais, M.; Galioto, M.; Padedda, B.M.; Lugliè, A.; Iaccarino, C.; Crosio, C. Cyanobacteria, Cyanotoxins, and Neurodegenerative Diseases: Dangerous Liaisons. Int. J. Mol. Sci. 2021, 22, 8726. https://doi.org/ $10.3390 /$ ijms 22168726

Academic Editors: Masaru Tanaka and László Vécsei

Received: 12 July 2021

Accepted: 5 August 2021

Published: 13 August 2021

Publisher's Note: MDPI stays neutral with regard to jurisdictional claims in published maps and institutional affiliations.

Copyright: (c) 2021 by the authors. Licensee MDPI, Basel, Switzerland. This article is an open access article distributed under the terms and conditions of the Creative Commons Attribution (CC BY) license (https:/ / creativecommons.org/licenses/by/ $4.0 /)$.

\begin{abstract}
The prevalence of neurodegenerative disease (ND) is increasing, partly owing to extensions in lifespan, with a larger percentage of members living to an older age, but the ND aetiology and pathogenesis are not fully understood, and effective treatments are still lacking. Neurodegenerative diseases such as Alzheimer's disease, Parkinson's disease, and amyotrophic lateral sclerosis are generally thought to progress as a consequence of genetic susceptibility and environmental influences. Up to now, several environmental triggers have been associated with NDs, and recent studies suggest that some cyanotoxins, produced by cyanobacteria and acting through a variety of molecular mechanisms, are highly neurotoxic, although their roles in neuropathy and particularly in NDs are still controversial. In this review, we summarize the most relevant and recent evidence that points at cyanotoxins as environmental triggers in NDs development.
\end{abstract}

Keywords: cyanobacteria; cyanotoxins; neurodegenerative diseases; ALS; Amyotrophic Lateral Sclerosis; PD; Parkinson's Disease; AD; Alzheimer Disease; L-BMAA

\section{Introduction}

The aetiology and pathogenesis of neurodegenerative diseases (NDs) such as Alzheimer's disease (AD), Parkinson's disease (PD), and amyotrophic lateral sclerosis (ALS) are not fully understood. All these neurodegenerative disorders have a significant genetic contribution, although mendelian forms of NDs, attributed to rare gene mutations, may account only for up to $5-10 \%$ of the cases, and the remaining $90-95 \%$ are due to idiopathic mechanisms. Recent high-throughput genomic technologies have demonstrated that the NDs share common genetic factors, and microarrays and next-generation RNA-sequencing point to shared gene expression signatures, such as neuroinflammation genes [1], with further overlaps identified in genes related to RNA splicing and protein turnover between ALS and PD and mitochondrial dysfunction genes as a common theme between PD and AD. Moreover, a recent meta-analysis study on -omic data obtained at all gene expression levels reveals significant overlaps between the different diseases [2].

Patients affected by NDs share common genetic patterns, although a consistent percentage of sporadic cases may have causes other than or in addition to human hereditary factors. The non-genetic factors may include the involvement of a variety of environmental factors, such as toxins, produced naturally by microorganisms. Table 1 summarizes some of the most representative epidemiological data, verified by meta-analysis, linking NDs to environmental factors. 
Table 1. Environmental factors in neurodegenerative diseases.

\begin{tabular}{|c|c|c|c|}
\hline Environmental Factors & Effects & Diseases & Reference \\
\hline \multirow{3}{*}{ Heavy metals } & $\begin{array}{l}\text { Lead (crosses the blood-brain barrier and accumulates } \\
\text { in neuronal and glial cells) }\end{array}$ & ALS $^{1}$ & {$[3,4]$} \\
\hline & Aluminium & $\mathrm{AD}^{2}$ & {$[5,6]$} \\
\hline & Manganese & $\mathrm{PD}^{3}$ & {$[6,7]$} \\
\hline \multirow{3}{*}{ Pesticide } & Pentachlorobenzene & ALS & [8] \\
\hline & Rotenone and paraquat & ALS, PD & {$[9,10]$} \\
\hline & Organophosphate pesticides & ALS, PD, AD & [11] \\
\hline Electromagnetic fields & Contradictory results & ALS, AD & [12-14] \\
\hline \multirow{2}{*}{ Smoking } & Protective & PD & {$[15,16]$} \\
\hline & Risk factor & $\mathrm{AD}, \mathrm{ALS}$ & {$[17,18]$} \\
\hline Physical activity & Protective & PD & [19] \\
\hline Body mass index and nutritional state & Lower nutritional parameters & $\mathrm{AD}$ & [20] \\
\hline \multirow{3}{*}{$\begin{array}{l}\text { Microbiota structure } \\
\text { and dysfunction of the gut-brain axis }\end{array}$} & $\begin{array}{l}\text { Akkermansia muciniphila reduces symptoms; } \\
\text { Ruminococcus torques and Parabacteroides distasonis }\end{array}$ & ALS & {$[21,22]$} \\
\hline & $\begin{array}{l}\text { Suppression of Prevotellaceae and anti-inflammatory } \\
\text { genera; blooming of pro-inflammatory Proteobacteria, } \\
\text { Enterococcaceae, and Enterobacteriaceae }\end{array}$ & PD & [23-25] \\
\hline & $\begin{array}{l}\text { Suppression of anti-inflammatory taxa such as } \\
\text { Eubacterium rectale and a profusion of } \\
\text { pro-inflammatory taxa such as Escherichia and Shigella }\end{array}$ & $\mathrm{AD}$ & {$[24,26]$} \\
\hline Cyanobacteria and cyanotoxins & Risk factors & ALS, PD, AD & {$[27,28]$} \\
\hline
\end{tabular}

${ }^{1}$ ALS, Amyotrophic Lateral Sclerosis, ${ }^{2}$ AD, Alzheimer's Disease, ${ }^{3}$ PD, Parkinson's Disease.

Cyanobacteria and microalgae synthesize significant quantities of toxins that can act via multiple molecular mechanisms $[29,30]$. Recent studies showing the presence of the neurotoxin $\beta$-N-methylamino-L-alanine (L-BMAA), produced by cyanobacteria and algal species, in the brain and cerebro-spinal fluid samples from patients with $\mathrm{AD}$ and ALS suggest that exposure to cyanotoxins may contribute to the development of human neurodegenerative diseases [27,31,32]. However, understanding the neurotoxic effects of L-BMAA and other microalgal neurotoxins and identification of pharmacological strategies to attenuate these harmful effects is needed.

Harmful algal blooms (HABs) represent a natural phenomenon caused by the growth of single or more species of phytoplankton at the same time. The harmful algal species (HAS) may belong to two different kingdoms of life, prokaryotic cyanobacteria and eukaryotic microalgae in waterbodies. In the last decades, HABs have had an evident increase in connection to human impacts such as eutrophication, aquaculture, hydrodynamic modifications in coastal systems, and global climate change [33]. Part of this observed HAB expansion reflects a better assessment of the current and past scale of the phenomenon, long obscured by scarce monitoring [34].

Over recent decades, it has been demonstrated that increasing anthropogenic activities, such as intensive agriculture and farming, industrialization, and urbanization, have led to the widespread eutrophication of inland and coastal ecosystems, resulting in a range of environmental, social, and economic issues due to the degradation of water resources $[35,36]$. Eutrophication causes shifts in the aquatic ecosystem's state, leading to a loss of ecosystem goods and services [37]. In fact, the quantity and quality of nutrient inputs to a water body can have profound effects upon its ecosystem processes and structure, e.g., acting on its biogeochemistry and biodiversity and altering the water quality. Eutrophication has many negative effects, among which one of the most worrying is the increased growth of microalgae [38] and cyanobacteria [39,40] that interfere with the use of waters [41]. Their blooms contribute to a range of problems, including fish kills, foul odors, unpalatability of drinking water, and hazards for human health [40]. 
The nutrient supplies to water bodies originate from different sources, such as external inputs, including catchment drainage, groundwater, and the atmosphere, and internal inputs, such as release from sediments. Strong relationships have been demonstrated between total phosphorus inputs and phytoplankton production in freshwaters [42-44], where $\mathrm{N}_{2}$ fixing cyanobacteria often dominate, compensating for any deficit in nitrogen [45,46], as well for the intake of total nitrogen in estuarine [47] and marine waters [48,49], on a worldwide scale. Changes in nutrient supply ratios, particularly for mineral (N:P or N:Si) and organic forms (DOC:DON), are responsible for the rearrangement of phytoplankton assemblages in favor of dominant species, which can lead to the formation of blooms [50-52]. Despite progress in our knowledge of the mechanisms by which nutrients are supplied to ecosystems and the pathways by which different species absorb them, the connections between nutrient supply and bloom growth, as well as their potential toxicity or damage, remain poorly understood [53]. The increase in the abundance of algal prey is also responsible for the widespread heterotrophic and mixotrophic species among HAB [54,55]. The ecological success of a microalgae or cyanobacteria species is influenced by biological factors, such as the presence and abundance of other species, grazers [56], and abiotic factors, such as the flushing rate or water residence time, weather conditions, water mixing, and stratification. The overall impact of nutrient overabundance on hazardous algal species is strongly species-specific. Control and reductions of nutrients have been demonstrated as the only effective and structural solution to preventing phytoplankton biomass or HAB incidence [57].

The HAS, mainly represented by dinoflagellates, diatoms, and cyanobacteria, produce significant environmental impacts due to high biomass and/or toxin production (Figure 1).
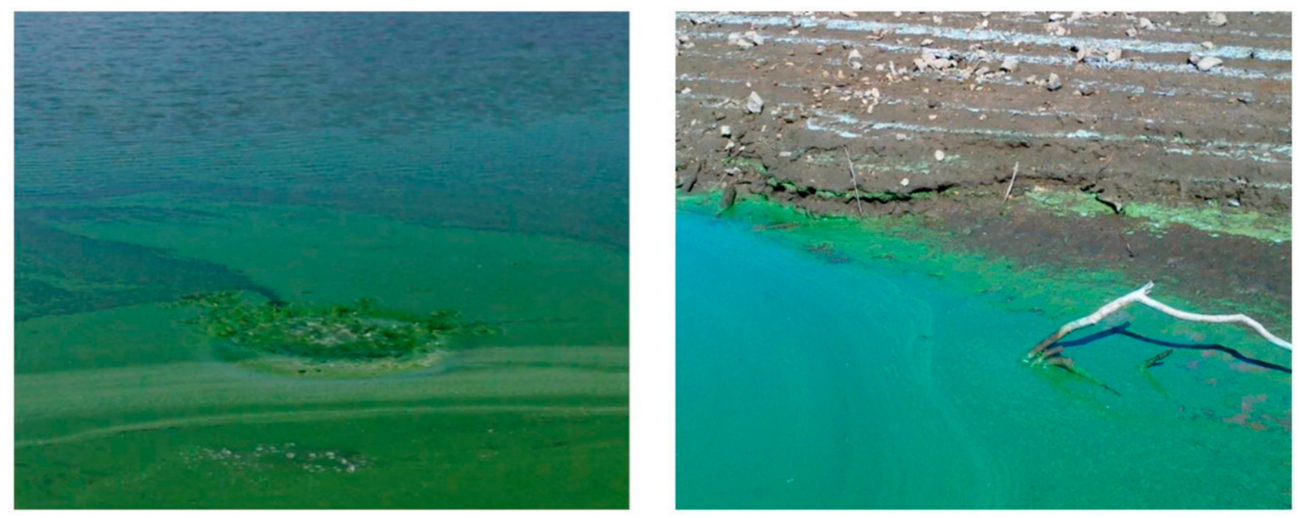

Figure 1. Evidence of intense cyano-HABs in Mediterranean artificial lakes (Sardinia; Lake Bidighinzu, on the left; Lake Posada, on the right). Cyanobacterial cell accumulation along shorelines, especially due to winds action, provokes blue-green colored waters.

Collectively, cyanotoxins and algal toxins have been implicated in an array of human diseases. In particular, the consumption of food contaminated by algal toxins results in various pathological conditions including seafood poisoning syndromes (diarrhetic shellfish poisoning-DSP, paralytic shellfish poisoning-PSP, neurotoxic shellfish poisoning-NSP, ciguatera fish poisoning-CFP, due to dinoflagellates; amnesic shellfish poisoning-ASP, due to diatoms). Human contact with aerosol or waterborne toxins can also have other minor deleterious impacts, such as dermatological or respiratory irritation [58]. Moreover, there is increasing epidemiological evidence of relationships between environmental toxins and neurodegenerative diseases, including ALS, AD, and PD $[27,59,60]$.

Most of these pathological conditions are caused by neurotoxins, which show highly specific effects on the nervous system of animals, including humans, by interfering with nerve impulse transmission. Neurotoxins are a varied group of compounds, both chemically and pharmacologically. They vary in both chemical structure and mechanism of 
action and produce very distinct biological effects, which provide a potential application of these toxins in pharmacology and toxicology.

Whereas dinoflagellates and diatoms are found primarily in marine environments, cyanobacteria are usually considered the major HAS in freshwater ecosystems. Actually, their impacts on transitional aquatic ecosystems may increase due to global climatic change [61]. Cyanobacteria produce an impressive range of toxic secondary metabolites, the cyanotoxins, whose presence and concentration in the waters is both a relevant threat to human health and the environment and a substantial economic cost [62,63]. Cyanobacteria are ancient, cosmopolitan inhabitants of terrestrial environments and fresh, transitional, and marine ecosystems; they are photosynthetic and prokaryotic organisms, classified in 150 genera, over 40 of which include species that produce cyanotoxins [64]. Cyanobacteria are fundamental components of phytoplankton, and their competitiveness, which depends on both biological traits and environmental conditions, allows them to dominate the phytoplankton of eutrophic and hypereutrophic water bodies. Interestingly, cyanobacteria have been globally growing due to the increase of the geographical distribution, including in the Mediterranean region, frequency, and extent of their harmful blooms (cyano-HABs), which are expected to further increase due to climate change $[65,66]$. Exposure to cyanotoxins, responsible for acute or (sub)chronic poisonings of wild/domestic animals and humans, can follow multiple routes: i) orally, via drinking water or via consumption of health food tablets or other organisms that have accumulated the cyanotoxins along the food chains; ii) in labour or recreational water environments dermally; or iii) by inhalation exposure [67].

Cyanotoxins are grouped, according to the physiological systems, organs, tissues, or cells that are primarily affected, in neurotoxins, hepatotoxins, cytotoxins, irritants, and gastrointestinal toxins. Many cyanotoxins are also tumor promoters, with carcinogenic activity, and are the causative agents of serious health threats for humans [68].

The purpose of this review is to summarize the scientific information on the relationship between neurodegenerative disorders and cyanobacterial/dinoflagellates neurotoxins, classified according to [69], focusing on the experimental models used to test CTX toxicity.

\section{Cyanobacterial and Dinoflagellates Neurotoxins}

According to [28,70], cyanobacterial and dinoflagellates neurotoxins can be divided in four main classes, based on their mode of action:

saxitoxins (carbamate compounds, $\mathrm{N}$-sulfocarbonyl compunds, decarbamyl compunds); ciguatoxins;

anatoxins (anatoxin-a, homoanatoxin-a, guanitoxin);

$\beta-\mathrm{N}$-methylamino-L-alanine (L-BMAA) and its isomers (2,4-diaminobutyric acid, 2,4-DAB and aminoethylglycine, AEG);

\section{Saxitoxins and the Paralytic Shellfish Poisoning}

Saxitoxin (STX) and its 57 analogues, collectively indicated as paralytic shellfish toxins (PSTs), are a family of molecules consisting of a tetrahydropurine group and two guanidinium moieties, produced by both cyanobacteria and dinoflagellates [70,71].

The most well-known and researched source of the PSTs is marine dinoflagellates (e.g., Alexandrium), which are filtered by invertebrates such as shellfish, crustaceans, and molluscs without being affected by the toxins. The toxins become concentrated in the invertebrates and are then ingested by human consumers, causing paralytic shellfish poisoning (PSP). There are strict safety guidelines for commercially produced seafood that establish a shellfish harvesting prohibition if toxin levels exceed a maximum of $800 \mu \mathrm{g}$ STX eqv /1000 g edible tissue [72].

STX is one of the strongest natural neurotoxins, and it is also the most studied among PSTs [71]. STX is a reversible voltage-gated sodium channel blocker (Figure 2A) [73]. It crosses the blood-brain barrier and acts by blocking sodium channels in the central nervous system (CNS), therefore leading to paralytic effects [74]. A critical issue related to low-dose extended exposure of coastal communities who rely heavily on a seafood diet 
is the study of the molecular mechanisms underlying STX toxicity. Exposure to STXs of cultured primary murine motoneurons as well neuronal cell lines (PC12 and SH-SY5Y cell lines) induces a reduction in axonal growth that is dependent on the presence of voltage-gated sodium channel isoform Nav1.9 [66,75]. Interestingly, the pharmacological activation to increase the opening probability of NaV1.9 could be a way to stimulate axon regeneration and maintenance in human neurodegenerative pathology such as spinal muscular atrophy (SMA), in which a defect in synapse maintenance appears as a central pathophysiological mechanism.

\section{A.Saxitoxins and Ciguatoxins}

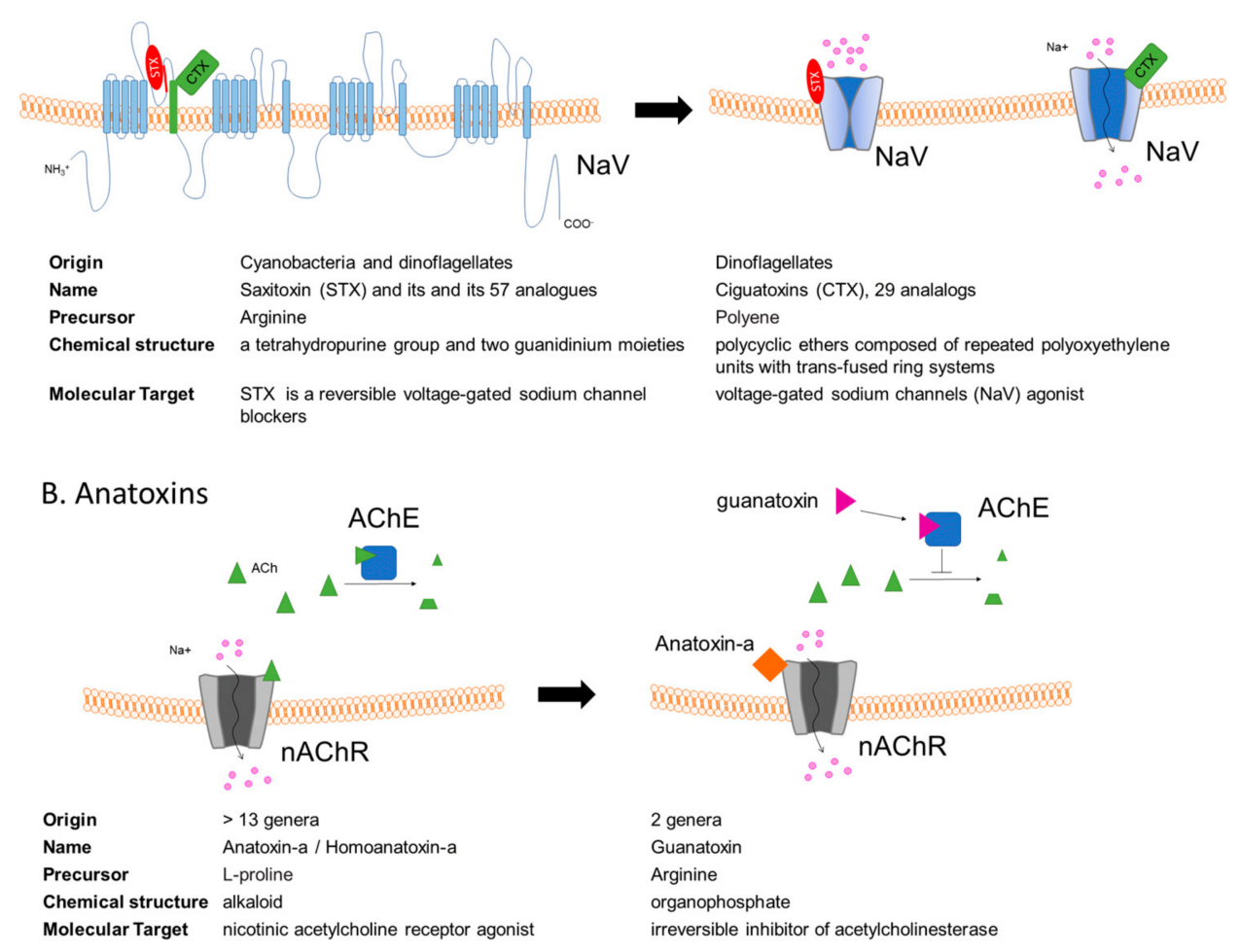

Figure 2. (A)Voltage-gated sodium channel (NaV) is the target of both saxitoxins (STXs) and ciguatoxins (CTXs). STX binding induces a block in $\mathrm{Na}^{+}$conduction, while CTX binding slows down $\mathrm{NaV}$ inactivation. (B) Anatoxins act on the nicotinic acetylcholine receptor (nAchR): anatoxin-a is a nAChR receptor agonist, mimicking the binding of its natural ligand, acetylcholine (Ach), while guanatoxin inhibits acetylcoline esterase (AChE), inducing ACh accumulation at the neuromuscular junction.

A low dose of STXs induces an altered redox status that results in oxidative stress in different experimental paradigms, as reported in Table 2.

Recently, a proteomic study on murine neuroblastoma N2A cells identified different proteins altered upon low-dose saxitoxin exposure. The identified proteins are key regulators of cell apoptotic pathways, cell skeleton maintenance, membrane potentials, and mitochondrial functions [31]. Notably low doses of saxitoxins induce a decrease in voltage-dependent anion-selective channel 1 (VDAC1). VDAC1 is a multifunctional protein, expressed in the mitochondria and other cell compartments, that regulates the main metabolic and energetic functions of the cell (Ca2+ homeostasis, oxidative stress, and mitochondria-mediated apoptosis) [32]. Notably, VDAC1 represents the main mitochondrial docking site of many misfolded proteins, such as amyloid $\beta$ and Tau in AD, $\alpha$-synuclein in PD and several SOD1 mutants in ALS [33]. In AD post-mortem brains as well as in APP1 transgenic mouse models, VDAC1 was found to be over expressed in patients, and the possibility of decreasing it by using low doses of STX can be a fascinating therapeutic option [33]. 
Table 2. Saxitoxins treatment in different experimental models.

\begin{tabular}{|c|c|c|c|}
\hline $\begin{array}{l}\text { Experimental } \\
\text { Model }\end{array}$ & Saxitoxins Exposure Protocol & Effects & Reference \\
\hline $\begin{array}{l}\text { primary neuron culture from } \\
\text { tropical freshwater fish }\end{array}$ & $0.3-3.0 \mathrm{mg} \mathrm{L}^{-1} 24 \mathrm{~h}$ & $\begin{array}{l}\text { oxidative stress, neurotoxicity, } \\
\text { genotoxicity and apoptosis }\end{array}$ & [76] \\
\hline murine neuroblastoma N2A & $0-256$ nM 24-48 h & $\begin{array}{l}\text { high levels of ROS generation } \\
\text { mild cytotoxic or apoptotic effects }\end{array}$ & [77] \\
\hline $\begin{array}{l}\text { rainbow trout fish cell line } \\
\text { RTG-2 }\end{array}$ & $0-256$ nM 24-48 h & mild cytotoxic or apoptotic effects & [77] \\
\hline human primary astrocytes & & $\begin{array}{c}\text { high levels of ROS generation reduced } \\
\text { cell survival }\end{array}$ & [78] \\
\hline zebrafish embryos & $0.05-0.1 \mu \mathrm{M}$ & $\begin{array}{l}\text { adverse effect on development of } \\
\text { zebrafish embryos, oxidative } \\
\text { stress-induced apoptosis }\end{array}$ & [79] \\
\hline mouse neonate brain & $\begin{array}{l}\text { single intraperitoneal } 7.5 \mu \mathrm{g} \mathrm{kg}^{-1} \\
\text { body weight in pregnant mice }\end{array}$ & $\begin{array}{l}\text { increased proliferation of OPCs, but not } \\
\text { maturation process of these cells }\end{array}$ & [80] \\
\hline
\end{tabular}

\section{Ciguatoxins}

Ciguatoxins (CTXs) are polyether marine toxins known to activate voltage-gated sodium channels $(\mathrm{NaV})$ and to cause one of the most widespread forms of nonbacterial food poisoning, named ciguatera. They are produced by dinoflagellates (i.e., Gambierdiscus) and reach humans via the food chain, with the consumption of fish that graze on reef macroalgae, including dinoflagellates that produce CTXs.

CTX-caused food poisoning was endemic only in tropical and subtropical areas, but it is spreading in Europe and Australia. Despite the high number of cases, estimated at around 50,000-500,000 cases per year, the prognosis is usually benign. In humans, more than 170 non-specific symptoms have been reported, although the most characteristic manifestations of ciguatera fish poisoning, found in all patients, are neurological symptoms, including paraesthesia and headache [81].

At present, more than 29 different CTX analogues have been identified, and they have been classified into three main groups that differ slightly in chemical structure according to the origin of the toxin: P for Pacific, C for the Caribbean, and I for Indian ciguatoxins [82] (Table 3).

Several lines of evidence suggest that chronic exposure to P-CTX-1 is associated with severe neurological manifestations in the peripheral nervous system (PNS) of some patients, suggesting that P-CTX-1 neurotoxicity, similar to other peripheral neuropathologies, primarily affects the PNS. In line with this hypothesis, it has been demonstrated, in mouse models, that the persistence of P-CTX-1 in peripheral nerves reduces the intrinsic growth capacity of peripheral neurons, resulting in delayed functional recovery after injury [83]. Moreover, P-CTX-1 has been shown to be a relatively non-selective activator of human $\mathrm{NaVs}$ subtypes (Figure 2A, displaying different functional effects on the different $\mathrm{NaV}$ subtypes, differentially expressed in peripheral sensory neurons [84]. It has been recently demonstrated that local application of $1 \mathrm{nM}$ P-CTX-1 into the skin of human subjects induces a long-lasting, painful axon reflex flare and that CTXs are particularly effective in releasing calcitonin-gene related peptide (CGRP) from nerve terminals [85]. Significant alteration in CGRP expression has been also observed in the anterior horn of the spinal cord of familial ALS patients as well as in the transgenic mice expressing mutated human SOD1, one of the most-used ALS mice models [86]. In this ALS mouse model, the genetic deletion of CGRP accelerates muscle denervation and reduces cytotoxic neuroinflammation [87]. Interestingly, in the spinal cord of wobbler mice, a well-established model of motor neuron loss, an increase in mRNA of CGRP and its receptor, has been observed [88].

Additionally, CNS neuron physiology is altered upon CTXs exposure since synthetic ciguatoxin P-CTX-3C has been shown to have a profound effect on neuronal transmission 
in mice primary cortical neurons [89]. The transcriptomic analysis of cortical neurons exposed for different time points to P-CTX-3C led to the identification of different signaling pathways activated downstream to the activating $\mathrm{NaVs}$ [90].

P-CTX-3C induces cytotoxicity in SHSY5Y human neuronal cells, only in the presence of the $\mathrm{Na}^{+}$channel activator (veratridine) and of the inhibitor of the $\mathrm{Na}^{+} / \mathrm{K}^{+}$ATPase (ouabain), mimicking a realistic human in vivo situation [91].

Interesting results were obtained using a tetracyclic analogue of ciguatoxin-like toxin, gambierol, in cellular and animal models for AD. In fact, although gambierol exhibits a potent acute lethal toxicity in mice (minimal lethal dose: $50 \mu \mathrm{g} / \mathrm{kg}$, ip), its tetracyclic truncated analogue in a mouse model for AD induces a decrease of amyloid $\beta 1-42$ level, a reduction of tau phosphorylation, and a reduction in the N2A subunit of the N-methyl-Daspartate (NMDA) receptor level [92].

Table 3. Ciguatoxins treatment in different experimental models.

\begin{tabular}{|c|c|c|c|c|}
\hline $\begin{array}{l}\text { Experimental } \\
\text { Model }\end{array}$ & $\begin{array}{l}\text { Ciguatoxins Exposure } \\
\text { Protocol }\end{array}$ & Molecular Target & effects & Reference \\
\hline SH-SY5Y & $\begin{array}{l}25 \mathrm{pM}-100 \mathrm{nM} \text { P-CTX-3C } \\
\text { short-(4-24 h) and long-term } \\
\text { exposure (10 days) }\end{array}$ & & $\begin{array}{l}\text { cytotoxic effect, alterations of } \\
\text { the mitochondrial metabolism, } \\
\text { cell morphology, and }\left[\mathrm{Ca}^{+}\right] \mathrm{i}\end{array}$ & [91] \\
\hline $\begin{array}{l}\text { primary cortical } \\
\text { neurons }\end{array}$ & $\begin{array}{c}5 \mathrm{nM} \mathrm{CTX3C} \mathrm{6-24-} \\
72 \mathrm{~h}\end{array}$ & & $\begin{array}{l}\text { gene expression alteration } \\
\text { mediated by voltage-gated } \\
\text { sodium channel }\end{array}$ & [90] \\
\hline $\begin{array}{l}\text { C57BL/6 } \\
\text { mice }\end{array}$ & $\begin{array}{l}\text { shallow intraplantar (i.pl.) } \\
\text { injection of P-CTX-1 (1-10 nM) }\end{array}$ & $\begin{array}{l}\text { Nav } 1.8 \text { and TTXs Nav } \\
\text { subtypes are effectors } \\
\text { of ciguatoxin-induced } \\
\text { cold allodynia }\end{array}$ & spontaneous pain & [93] \\
\hline $\begin{array}{l}\text { transgenic mice and } \\
\text { rat }\end{array}$ & $\begin{array}{l}\text { 0.01-31 nM P-CTX-1 (>95\% } \\
\text { purity) isolated from moray eel } \\
\text { (Gymnothorax javanicus) liver }\end{array}$ & NaV1.9 & $\begin{array}{c}\text { release of calcitonin-gene } \\
\text { related peptide (CGRP) from } \\
\text { nerve } \\
\text { terminals }\end{array}$ & [85] \\
\hline $\begin{array}{l}\text { C57BL/6 } \\
\text { mice }\end{array}$ & $\begin{array}{c}\text { (0.26 ng/g body weight) } \\
\text { intraperitoneally on day } 0 \\
\text { followed by second exposure } \\
\text { on day } 3 \text { P-CTX-1 (isolated and } \\
\text { purified from moray eels) }\end{array}$ & & $\begin{array}{l}\text { irreversible motor deficit in } \\
\text { 4-month pre-exposed mice } \\
\text { following peripheral nerve } \\
\text { injury } \\
\text { astrogliosis and excitotoxic } \\
\text { neuronal cell death via the } \\
\text { activation of caspase } 3 \text { in } \\
\text { motor cortex }\end{array}$ & [94] \\
\hline
\end{tabular}

\section{Anatoxins}

Anatoxins are water-soluble cyanotoxins (produced by different cyanobacterial genera, e.g., Anabaena, Dolichospermum, Aphanizomenon; Figure 3), lethal neurotoxins that can be classified into three main categories: anatoxin-a, its structural homologue homoanatoxin-a, and the unrelated guanitoxin, previously named anatoxin-a(s) [95].

Anatoxin-containing blooms have been found all over the world. As represented in Figure 2B, they have different physiological targets: (i) anatoxin-a is an alkaloid and an agonist of nicotine acetylcholine receptors (nAChRs), which are located both in the CNS as well as in the postsynaptic terminals of motor neurons, [96]; (ii) guanitoxin is an organophosphate that acts as an irreversible inhibitor of acetylcholinesterase (AChE, EC3.1.1.7) [28]. Notably, neuronal nAChRs are considered potential targets for the development of new therapeutic agents for the treatment of diverse disorders such as PD and $\mathrm{AD}[97,98]$, while AChE inhibitors have been demonstrated to be effective in slowing the clinical progression in AD patients [99]. 
Anatoxin-a was shown, at least in vitro, to induce inflammation and apoptosis in immune and brain cells [100], and it has been implicated in numerous animal poisonings worldwide. Up to date, there is no evidence of its toxic effects on the brain, and more detailed experiments are needed to find a link, if any, between anatoxin exposure and neurodegeneration.
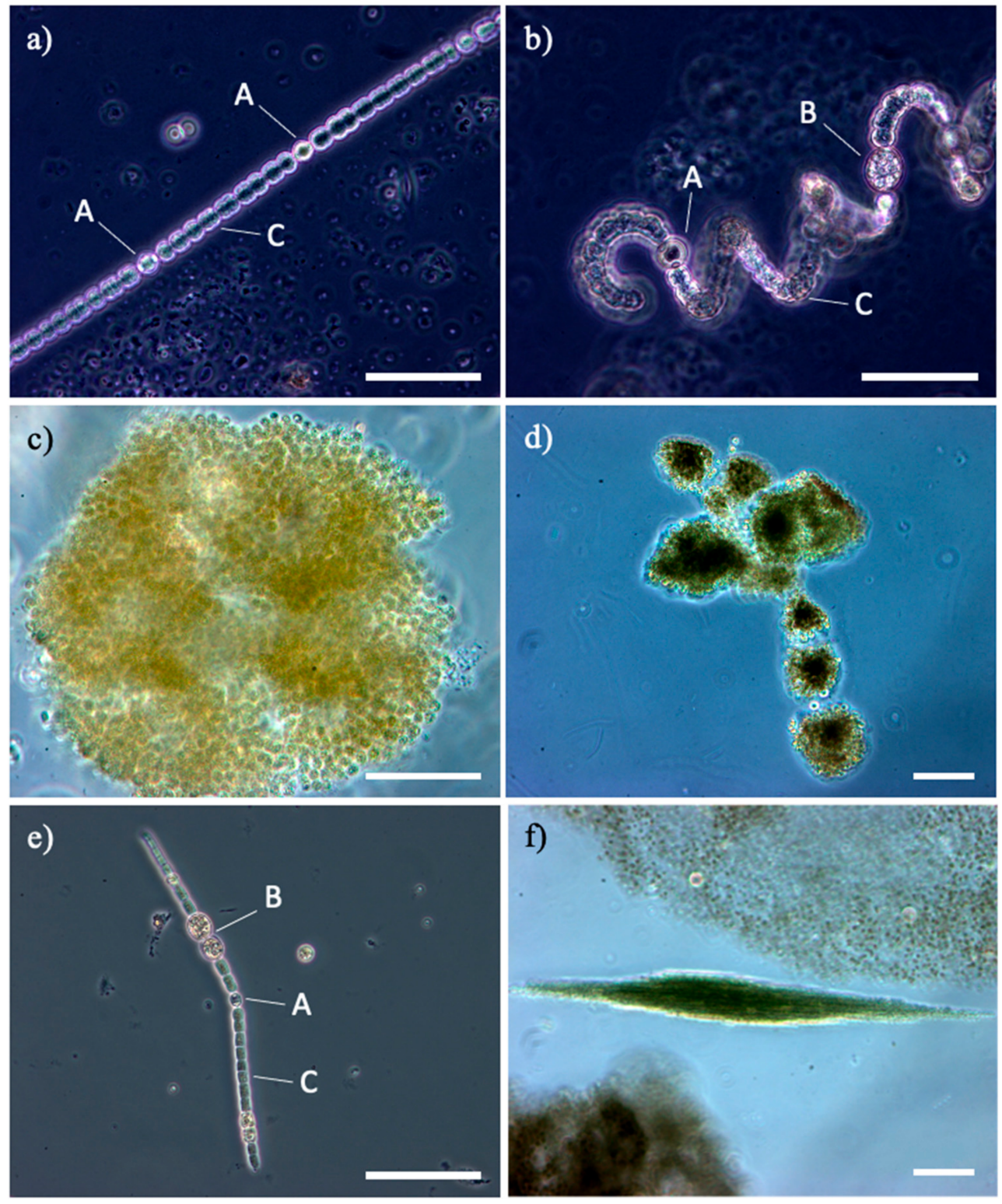

Figure 3. Cyanobacteria genera, potentially toxins producers in Mediterranean artificial lakes: $(\mathbf{a}, \mathbf{b})$ : different species of Dolichospermum from Lake Bidighinzu; (c,d): different species of Microcystis from Lake Liscia and Lake Monte Lerno; $(\mathbf{e}, \mathbf{f})$ : different species of Aphanizomenon, in single tricome from Lake Temo and in fascicle of tricomes from Lake Liscia. A: heterocyst, B: akinete; C: vegetative cells; bar $50 \mu \mathrm{m}$.

\section{Role of L-BMAA in Neurodegenerative Diseases}

L-BMAA was isolated for the first time from the seeds of Cycas circinalis L. [54]. LBMAA is a non-protein neurotoxic amino acid produced almost from all known groups of cyanobacteria including cyanobacterial symbionts (e.g., Nostoc) and free-living cyanobacteria (e.g., Anabaena, Microcystis; Figure 3), marine diatoms (e.g., Navicula, Skeletonema), and dinoflagellates (e.g., Gymnodinium) in the most various ecosystems worldwide [101]. 
Despite some contradictory opinions [102], an increasingly large body of experimental outcomes provides significant evidence that L-BMAA plays an important role in slowdeveloping neurodegenerative diseases, including ALS/Parkinsonism Dementia Complex (ALS/PDC) found on Guam islands, ALS, AD, and PD (review [32,59]).

ALS/PDC, specific to Guam and certain other Marianas islands of the Western Pacific, with symptoms of all three diseases, came to the attention of the scientific community during and after World War II. In the 1950s, for Chamorro residents of Guam and Rota, ALS, ALS-like conditions, and their death rates were estimated to be 50-100 times higher than in the United States and in other developed countries. From the late 1960s to the early 1980s, the incidence of both disorders had decreased. The main causes responsible for the decreasing incidence appeared to be ethnographic, social, and ecological changes, brought about by the rapid westernization of Guam. This change suggests that the cause of the ALS/PDC was not genetic but rather environmental [103].

Since the indigenous Chamorro people consumed cycad seed flour in food and in traditional medicine, Spencer et al. [104] first proposed the connection between the etiopathogenesis of ALS/PDC and the neurotoxin L-BMAA produced by the cyanobacteria of the genus Nostoc, which are symbiont of coralloid roots cycads. In a preliminary study, Spencer et al. showed that repeated oral administration of L-BMAA (0-81 $\mathrm{mmol} / \mathrm{kg}$ daily) to Macaca fascicularis monkeys was able to induce a degenerative motor-system disease with features of ALS and parkinsonism. Pyramidal dysfunction, limb weakness, atrophy, upperextremity tremors and wrist drop, bradykinesia, behavioral changes, and degeneration of lower motor neurons were observed [104].

A significant finding in the primate study of Spencer et al. was that, while early signs of motor-neuron dysfunction were observed in animal models fed with high doses of L-BMAA, extrapyramidal damage developed slowly with lower doses of L-BMAA. This led the authors to propose that chronic toxicity might be separate from acute toxicity [60]. Interestingly, L-BMAA is then biomagnified up the food chain from symbiotic cyanobacteria to cycads to flying fox of the genus Pteropus mariannus. Cox et al. [105] observed a 10,000-fold biomagnification of free L-BMAA and 50-fold biomagnification in total L-BMAA. These data suggested a mechanism that could produce sufficiently high doses of toxins to induce neurological disease in humans [106-108].

Biomagnification of L-BMAA may not be unique to Guam; indeed, Cox and colleagues [109] detected L-BMAA not only in the brain tissue of Chamorros who died from ALS-PDC but also in Alzheimer's patients from Canada due to the capability of the neurotoxin to cross the blood-brain barrier through an active transport mechanism $[110,111]$. This finding suggests various ecological pathways for the bioaccumulation of L-BMAA in aquatic or terrestrial ecosystems.

L-BMAA is neurotoxic, and although different and multiple mechanisms of toxicity have been proposed (Figure 4), its involvement in neurotoxicity and neurodegeneration remains largely unidentified $[112,113]$. The neurotoxin is a non-lipophilic, non-essential amino acid that is present both in free and protein-bound forms. Weiss and Choi discovered that L-BMAA had activity in vitro only when a physiological concentration $(10 \mathrm{mM}$ and higher) of bicarbonate ions ( $\left.\mathrm{HCO3}^{-}\right)$was co-present in the cell culture media. L-BMAA's carbamate adduct, named $\beta$-carbamate, presents structural similarities to glutamate that may lead to neuronal degeneration via a mechanism regulated by the activation of excitatory amino acid (EAA) receptors and/or glutamate transporters through a three-fold mechanism $[114,115]$. At a glutamatergic synapse, $\beta$-carbamate binds to ionotropic (NMDA and AMPA/kainate receptors) receptors (iGluR) and metabotropic receptors (mGluR). Their activation induces a significant increase in intracellular $\mathrm{Ca}^{2+}$, directly via iGluR and indirectly via mGluR (via phospholipase C signaling) [116], promoting mitochondrial reactive oxygen species (ROS) generation and endoplasmic reticulum (ER) stress [113]. This excitotoxicity of postsynaptic neurons typically leads to neuronal death. Besides being part of the pathogenic mechanism leading to ALS, excitotoxicity could be responsible for the selective vulnerability of motoneurons during the progression of the disease $[117,118]$. 


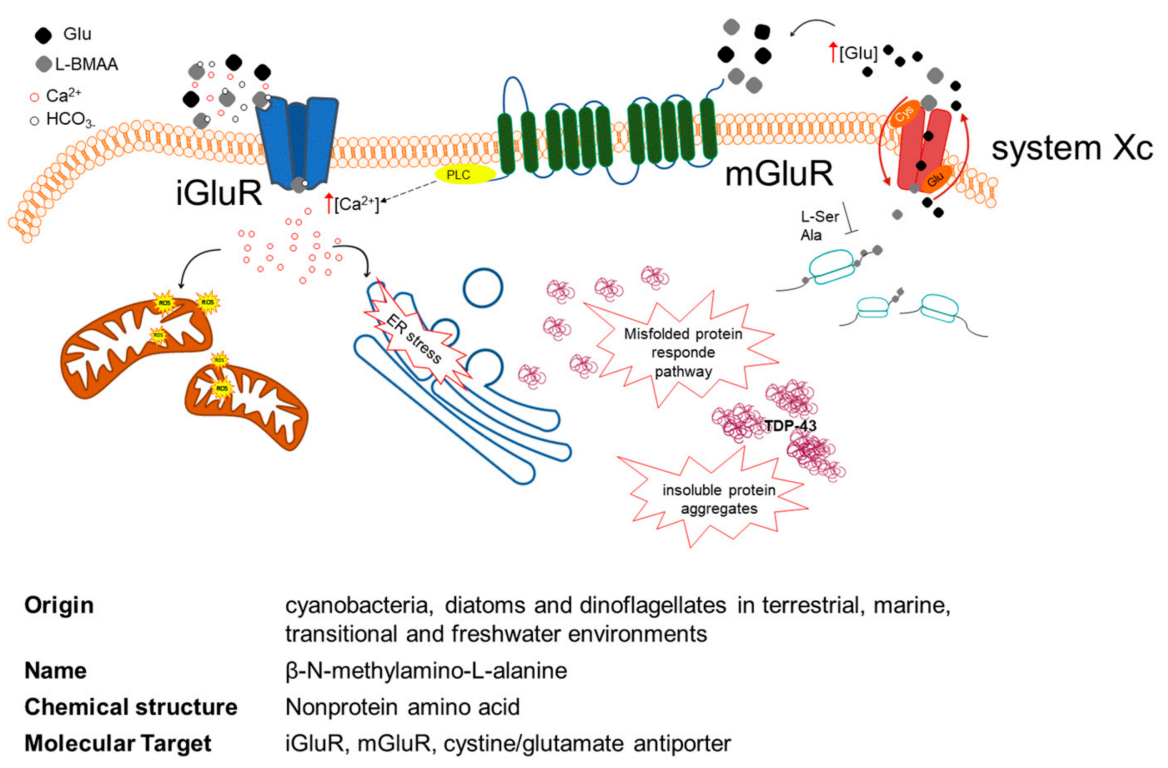

Figure 4. Multiple mechanisms of L-BMAA cellular toxicity. L-BMAA in the presence of bicarbonate ions (HCO3-) forms L-BMAA's carbamate adduct, named $\beta$-carbamate, and binds to ionotropic (iGluR) and metabotropic (mGluR) receptors. The activation of iGluR and mGluR leads to a significant increase in intracellular $\mathrm{Ca}_{2}{ }^{+}$, directly via iGluR and indirectly via mGluR (PLC signaling). This $\mathrm{Ca}_{2}{ }^{+}$increase promotes mitochondrial reactive oxygen species (ROS) generation and endoplasmic reticulum (ER) stress. L-BMAA inhibits the cystine/glutamate antiporter (system $\mathrm{Xc}_{\mathrm{c}-\text { )-mediated }}$ cystine uptake, which leads to glutathione depletion and increased oxidative stress. Once in the cytoplasm, the toxin is likely to be inserted into the neosynthesized cellular proteins and to prompt protein misfolding that often leads to the formation of insoluble aggregates, containing among other proteins TDP-43. iGluR: ionotropic glu receptors; mGluR: metabotropic glu receptors; PLC: phospholipase C; TDP-43: TAR DNA-binding protein 43.

Liu et al. in 2009 found that L-BMAA inhibits the cystine/glutamate antiporter (system $X_{c}-$-mediated cystine uptake, which leads to glutathione depletion and increased oxidative stress. In a cyclical system, L-BMAA seems to drive the release of glutamate through the Xc-system, which induces toxicity through the activation of the mGluR5 receptor. This transport may be the cause of L-BMAA accumulation in cells [118].

Once in the cytoplasm, the neurotoxin may probably be misincorporated in place of serine or alanine in neosynthesized cellular proteins. L-BMAA might also be associated with proteins through non-covalent bonds. The insertion of L-BMAA and other nonprotein amino acids into proteins may generate protein disfunction, misfolding, and/or aggregation. Although further research is required concerning L-BMAA incorporation into proteins, L-BMAA is incorporated into proteins in place of L-serine [119], and a large portion of L-BMAA is protein-bound (60- to 130-fold greater amount) compared to L-BMAA detected in the free $[119,120]$.

This incorporated L-BMAA in brain tissues may function as an endogenous neurotoxic reservoir that can slowly release free L-BMAA, causing neurological damage over years or even decades, which may explicate the observed long-latency period for neurological disease onset among the Chamorro people [32].

Protein misfolding often leads to the formation of insoluble aggregates, and anomalous accumulation of aggregates in the affected tissues is one of the main pathological changes observed in neurodegenerative diseases. In ALS, this phenomenon involves biological markers including TDP-43 (TAR DNA-binding protein 43), a protein encoded by the TARDBP gene, located in the cell nucleus of most tissues. In physiological conditions, TDP43 shuttles between the nucleus and cytoplasm, and it is involved in various steps of RNA biogenesis and processing such as alternative splicing [121,122]. In pathological conditions, 
TDP-43 is hyperphosphorylated, ubiquitinated, and cleaved to generate C-terminal fragments, and it was identified as the main component of ubiquitinated inclusions in post-mortem tissues of ALS patients and patients with frontotemporal dementia [122,123].

Triggers with L-BMAA result in TDP-43 overexpression and aggregation in several in vitro and in vivo models: SH-SY5Y cell lines [124] and primary neurons (rats [124,125], mice [126,127], and zebrafish [128]). These specific forms of TDP-43 are present in patients with neurodegenerative diseases such as ALS and FTD.

The protein misincorporation of L-BMAA could affect protein-folding and successive accumulation of misfolded proteins into lysosomes [119]. This anomalous protein-synthesis is also supposed to lead to cell stress at the endoplasmic reticulum, independent of LBMAA high concentration effects such as excitotoxicity and oxidative stress, deregulation of the reduction/oxidation systems, and an activation of some pro-apoptotic caspases like caspase-12 [129]. The resulting dysregulated protein homeostasis with low non-excitotoxic concentrations could be a contributing factor in the scenario of chronic L-BMAA exposure that may lead to late onset and slow progression of neurodegenerative diseases [129].

Moreover, L-BMAA leads to the activation of transcription factors known to be involved in the regulation of oxidative stress and cellular senescence such as X-box binding protein 1 and nuclear factor 2 erythroid like 2 [130]. Interestingly, the same high levels of these transcriptional regulators have been detected in the brains of patients with ALS, PD, $\mathrm{AD}$, and front temporal dementia [131,132].

Numerous investigators used in vitro approaches to assess the potential role of LBMAA on mammalian CNS models. It should be noted that most in vitro investigations needed high L-BMAA concentrations $(\geq 100 \mu \mathrm{M})$ to produce cellular damage and toxicity (Table 4). These concentrations are not physiologically appropriate, and consequently the results are extremely difficult to interpret compared to in vivo responses. Therefore, numerous studies identified a possible mechanism of toxicity at a cellular level but are incomplete in relating the effects to L-BMAA environmental exposures.

Chiu and colleagues [114] reported NMDA receptor-mediated increases in intracellular calcium ions, ROS production, DNA damage, and neuronal death in primary human neuronal cells prepared from foetuses following exposure to L-BMAA, with the lowest toxic concentration in the presence of bicarbonate reported to be $400 \mu \mathrm{M}$ [133]. The neuron-like cell lines are frequently chosen for their characteristics. SH-SY5Y, from human metastatic neuroblastoma, has dopaminergic, cholinergic, glutamatergic, and adenosinergic features; clonal rat pheochromocytoma cell line PC12, differentiated with nerve growth factor, is a recurrent model to study receptor-mediated excitotoxicity [134]. In order to investigate independent excitotoxic mechanisms, non-neuronal cells have also been used, but immortalized cells are significantly different from physiological characteristics in neurons; thus, numerous studies were made on primary neuronal cultures (Table 4).

Table 4. L-BMAA treatment in different experimental models.

\begin{tabular}{ccc}
\hline $\begin{array}{c}\text { Experimental } \\
\text { Model }\end{array}$ & $\begin{array}{c}\text { L-BMAA } \\
\text { Exposure Protocol }\end{array}$ & Molecular Target \\
& $\begin{array}{c}3 \mathrm{mM} \text { plus antagonist for } \\
\text { kainate/AMPA receptors 5 days }\end{array}$ & $\begin{array}{c}\text { low neurotoxicity of BMAA and weak action at } \\
\text { glutamatergic receptors }\end{array}$ \\
\cline { 2 - 3 } SH-SY5Y & $0.1 \mathrm{mM} \mathrm{48h}$ & $\begin{array}{c}\text { Low non-excitotoxic BMAA concentrations induce } \\
\text { effects on the ubiquitin/proteasome } \\
\text { system not ROS-related }\end{array}$ \\
\hline [135] & $\begin{array}{c}\text { [129] } \\
\text { decrease cell viability in a dose-response manner and } \\
\text { evoke alterations in GSK3 and TDP-43 }\end{array}$ \\
\hline
\end{tabular}


Table 4. Cont

\begin{tabular}{|c|c|c|c|}
\hline $\begin{array}{l}\text { Experimental } \\
\text { Model }\end{array}$ & $\begin{array}{c}\text { L-BMAA } \\
\text { Exposure Protocol }\end{array}$ & Molecular Target & Reference \\
\hline & $0.5 \mathrm{mM} 24 \mathrm{~h}-48 \mathrm{~h}-72 \mathrm{~h}$ & Increased caspase- 3 activity and cathepsins, ER stress & {$[137]$} \\
\hline & $0.05-0.25-1 \mathrm{mM} 24 \mathrm{~h}$ & $\begin{array}{c}\text { alterations in alanine, aspartate, and glutamate } \\
\text { metabolism }\end{array}$ & {$[138]$} \\
\hline & $0.1-1 \mathrm{mM} 24-48 \mathrm{~h}$ & autophagy & {$[139]$} \\
\hline & $3 \mathrm{mM} 48 \mathrm{~h}$ & disrupts mitochondrial metabolism & {$[140]$} \\
\hline \multirow{2}{*}{ PC12 } & $2 \mathrm{mM} 6-12 \mathrm{~h}$ & apoptosis and mGluR1 increase & {$[141]$} \\
\hline & $0.4-1 \mathrm{mM} 48 \mathrm{~h}$ & promoted cell death and axon-like outgrowth & {$[142]$} \\
\hline NSC-34 & $0.1-1 \mathrm{mM} 72 \mathrm{~h}$ & $\begin{array}{c}\text { exposure to BMAA causes protein misfolding, ER stress, } \\
\text { induction of the UPR, disruption of the mitochondrial } \\
\text { function }\end{array}$ & {$[130,141]$} \\
\hline $\mathrm{NIH} / 3 \mathrm{~T} 3$ & $1-3 \mathrm{mM} 48-96 \mathrm{~h}$ & $\begin{array}{l}\text { L-BMAA causes arrest of cell cycle progression at the } \\
\text { G1/S. No evidence of cell membrane damage, apoptosis, } \\
\text { or ROS overproduction }\end{array}$ & {$[143]$} \\
\hline primary cortical neurons & $\begin{array}{c}3 \mathrm{mM} 1 \mathrm{~h} \\
20 \mathrm{mM} \mathrm{HCO3}^{-}\end{array}$ & $\begin{array}{l}\text { L-BMAA activity is dependent on } \mathrm{HCO}^{-} \text {, resulting in a } \\
\text { destruction of cortical neuronal population. }\end{array}$ & $\begin{array}{l}{[115]} \\
{[144]}\end{array}$ \\
\hline $\begin{array}{l}\text { primary cerebellar } \\
\text { granule cells colture, rat }\end{array}$ & up to $3 \mathrm{mM} 24-48 \mathrm{~h}$ & $\begin{array}{l}\text { L-BMAA induced both necrotic- and apoptotic-like cell } \\
\text { death }\end{array}$ & {$[145]$} \\
\hline $\begin{array}{l}\text { primary neurons and } \\
\text { astrocytes cortical cell } \\
\text { cultures, fetal mouse }\end{array}$ & $\begin{array}{l}\text { 3-10 mM 3-24h } \\
0.1 \mathrm{mM} 48 \mathrm{~h}\end{array}$ & $\begin{array}{l}\text { enhancement death of cortical neurons damaged by other } \\
\text { insults; oxidative stress, Wallerian-Like Degeneration }\end{array}$ & {$[146-148]$} \\
\hline neural stem cells & $50 \mu \mathrm{M}-3 \mathrm{mM} 24 \mathrm{~h}$ & $\begin{array}{l}\text { apoptosis, cellular differentiation, neurite outgrowth, } \\
\text { and DNA methylation }\end{array}$ & {$[133]$} \\
\hline
\end{tabular}

The production of L-BMAA is not limited to cycad seeds, and the risk to exposure to this neurotoxin is not confined to Guam. In some locations, cyanobacteria are directly consumed by people. In the mountains of Peru, Cyanobacteria Nostoc commune Vaucher ex Bornet and Flahault (with a L-BMAA concentration of $10 \mu \mathrm{g} / \mathrm{g}$ ) are collected in the highland lakes by the indigenous people, who call them llullucha [149]. Indigenous people eat them directly, sell them in markets, and add them to salads, soups, or meat dishes. Direct dietary intake is not the only possible mode of exposure to cyanobacterial neurotoxins. Inhalation as a systemic delivery route has been demonstrated for microcystins in nasal swabs and blood samples from people at risk of swallowing water or inhaling spray while swimming, water skiing, jet skiing, or boating during algal blooms [150]. In 2009, a causative link was hypothesized between the inhalation of L-BMAA, present in soil crusts dominated by cyanobacteria and detected in desert dust, and the higher incidence of ALS observed in the Gulf war veterans younger than 45 years old [151], but experiments in rat models observed significant biochemical responses to L-BMAA only at extremely high (non-physiological) concentrations [152].

Notably, L-BMAA misincorporation into neuroproteins produces protein misfolding and is inhibited by L-serine $[108,139]$ that was proposed as a potential therapeutic option for ALS ([153] phase 2 ClinicalTrials.gov Identifier: NCT03580616), AD (Phase 2 ClinicalTrials.gov identifier: NCT03062449) and hereditary sensory autonomic neuropathy type I (HSAN1) [154]. The molecular mechanism underlying L-serine neuroprotection is not fully elucidated and can be independent of L-BMAA-mediated neurotoxicity [139].

\section{Conclusion}

An increasing cyanobacteria abundance is expected due to climate change and eutrophication, worsening the cyanotoxins issue and urging quick prevention and mitigation actions. Cyanobacteria detection in natural water samples with cyanotoxins (CTXs)-level determination should become a priority to prevent uncontrolled human exposure. Although pathophysiological mechanisms underlying ND is far from being completely understood, the link between CTX exposure and neurodegeneration is now widely accepted 
by the scientific community. Apart from the well-described via of CTXs exposure (ingestion, dermal contact, biomagnification), it could be critical also to evaluate the presence of cyanobacteria in gut microbiota. In this respect, in the last 10 years, a growing recognition within the scientific and medical communities points at the "microbiota-gut-brain axis" as a key element in neurodegenerative process (Table 1 and [155] for a comprehensive review). Different lines of investigation have suggested that some species of cyanobacteria are present in small numbers in the gastrointestinal tract, and through the production of specific CTX, they could be considered potentially responsible for inducing neurodegeneration [155-157]. At present, only in PD patients, a specific decrease in cyanobacteria (Family Aphanizomenonaceae, Genus Dolichospermum) has been reported [158]. The lack of data for other neurodegenerative disorders can be linked to the low abundance of Cyanobacteria in biological samples tested. Nevertheless, human beings can be, via dietary sources, chronically exposed to cyanotoxins and/or other algal toxins, single or in combinations, which can alter different cellular processes and activate specific immune responses, chronic mild gut inflammation, and ultimately neurodegenerative processes [59].

The present review aims to emphasize the relationship between the increasing number of HABs and eutrophication with the molecular evidence linking CTXs to neurodegeneration. A multidisciplinary approach is required to mitigate the human health risks and to fill different scientific gaps. It is of particular interest to test the hypotheses whether CTXs in water samples are linked to their trophic state, to cyanobacteria abundance and/or species composition living there, and finally at the molecular level, to definitively establish the contribution of CTX chronic exposure to neurodegeneration.

Author Contributions: Read the literature and original draft preparation: P.S., M.F., T.B.C.D., M.G., B.M.P., A.L., C.I., and C.C. Edit the paper: C.I. and C.C. All authors have read and agreed to the published version of the manuscript.

Funding: Fondo di Ateneo per la Ricerca 2019 Crosio. Fondazione di Sardegna (Bando-2017Iaccarino). Fondo di Ateneo per la Ricerca 2019 Iaccarino. P.S. and M.F. were supported by PhD fellowships granted by PON 2014-2020 (CCI2014IT16M2OP005). T.B.C.D. was supported by a Master Fellowship granted by Erasmus+-International Credit Mobility 2018-2019-Grant n²018-1-IT02KA107-047494.

Acknowledgments: We would like to acknowledge all the people from the molecular biology laboratory that critically read the manuscript.

Conflicts of Interest: The authors declare no conflict of interest.

\section{References}

1. Tanaka, M.; Toldi, J.; Vécsei, L. Exploring the Etiological Links behind Neurodegenerative Diseases: Inflammatory Cytokines and Bioactive Kynurenines. Int. J. Mol. Sci. 2020, 21, 2431. [CrossRef]

2. Ruffini, N.; Klingenberg, S.; Schweiger, S.; Gerber, S. Common Factors in Neurodegeneration: A Meta-Study Revealing Shared Patterns on a Multi-Omics Scale. Cells 2020, 9, 2642. [CrossRef]

3. Gunnarsson, L.-G.; Bodin, L. Amyotrophic Lateral Sclerosis and Occupational Exposures: A Systematic Literature Review and Meta-Analyses. Int. J. Environ. Res. Public Health 2018, 15, 2371. [CrossRef]

4. Wang, H.; Yi, J.; Li, X.; Xiao, Y.; Dhakal, K.; Zhou, J. ALS-Associated Mutation SOD1(G93A) Leads to Abnormal Mitochondrial Dynamics in Osteocytes. Bone 2018, 106, 126-138. [CrossRef]

5. Killin, L.O.J.; Starr, J.M.; Shiue, I.J.; Russ, T.C. Environmental Risk Factors for Dementia: A Systematic Review. BMC Geriatr. 2016, 16, 175. [CrossRef] [PubMed]

6. Cicero, C.E.; Mostile, G.; Vasta, R.; Rapisarda, V.; Signorelli, S.S.; Ferrante, M.; Zappia, M.; Nicoletti, A. Metals and Neurodegenerative Diseases. A Systematic Review. Environ. Res. 2017, 159, 82-94. [CrossRef]

7. Racette, B.A.; Nielsen, S.S.; Criswell, S.R.; Sheppard, L.; Seixas, N.; Warden, M.N.; Checkoway, H. Dose-Dependent Progression of Parkinsonism in Manganese-Exposed Welders. Neurology 2017, 88, 344-351. [CrossRef] [PubMed]

8. Su, F.-C.; Goutman, S.A.; Chernay, S.; Mukherjee, B.; Callaghan, B.C.; Batterman, S.; Feldman, E.L. Association of Environmental Toxins With Amyotrophic Lateral Sclerosis. JAMA Neurol. 2016, 73, 803-811. [CrossRef] [PubMed]

9. Tanner, C.M.; Kamel, F.; Ross, G.W.; Hoppin, J.A.; Goldman, S.M.; Korell, M.; Marras, C.; Bhudhikanok, G.S.; Kasten, M.; Chade, A.R.; et al. Rotenone, Paraquat, and Parkinson's Disease. Environ. Health Perspect. 2011, 119, 866-872. [CrossRef] 
10. Ascherio, A.; Schwarzschild, M.A. The Epidemiology of Parkinson's Disease: Risk Factors and Prevention. Lancet Neurol. 2016, 15, 1257-1272. [CrossRef]

11. Sánchez-Santed, F.; Colomina, M.T.; Herrero Hernández, E. Organophosphate Pesticide Exposure and Neurodegeneration. Cortex 2016, 74, 417-426. [CrossRef] [PubMed]

12. Gunnarsson, L.-G.; Bodin, L. Occupational Exposures and Neurodegenerative Diseases-A Systematic Literature Review and Meta-Analyses. Int. J. Environ. Res. Public Health 2019, 16, 337. [CrossRef]

13. Gunnarsson, L.-G.; Bodin, L. Alzheimer's Disease and Occupational Exposures: A Systematic Literature Review and MetaAnalyses; 2015; Volume 17. In Alzheimer's Disease \& Treatment. Available online: http:/ / openaccessebooks.com/alzheimersdisease-treatment/alzheimers-disease-and-occupational-exposures-a-systematic-literature-review-and-meta-analyses.pdf (accessed on 2 August 2021).

14. Riancho, J.; Sanchez de la Torre, J.R.; Paz-Fajardo, L.; Limia, C.; Santurtun, A.; Cifra, M.; Kourtidis, K.; Fdez-Arroyabe, P. The Role of Magnetic Fields in Neurodegenerative Diseases. Int. J. Biometeorol. 2021, 65, 107-117. [CrossRef]

15. Jacobs, B.M.; Belete, D.; Bestwick, J.; Blauwendraat, C.; Bandres-Ciga, S.; Heilbron, K.; Dobson, R.; Nalls, M.A.; Singleton, A.; Hardy, J.; et al. Parkinson's Disease Determinants, Prediction and Gene-Environment Interactions in the UK Biobank. J. Neurol. Neurosurg. Psychiatry 2020, 91, 1046-1054. [CrossRef]

16. Noyce, A.J.; Bestwick, J.P.; Silveira-Moriyama, L.; Hawkes, C.H.; Giovannoni, G.; Lees, A.J.; Schrag, A. Meta-Analysis of Early Nonmotor Features and Risk Factors for Parkinson Disease. Ann. Neurol. 2012, 72, 893-901. [CrossRef] [PubMed]

17. Wallin, C.; Sholts, S.B.; Österlund, N.; Luo, J.; Jarvet, J.; Roos, P.M.; Ilag, L.; Gräslund, A.; Wärmländer, S.K.T.S. Alzheimer's Disease and Cigarette Smoke Components: Effects of Nicotine, PAHs, and Cd(II), Cr(III), Pb(II), Pb(IV) Ions on Amyloid- $\beta$ Peptide Aggregation. Sci. Rep. 2017, 7, 14423. [CrossRef]

18. Menounos, S.; Hansbro, P.M.; Diwan, A.D.; Das, A. Pathophysiological Correlation between Cigarette Smoking and Amyotrophic Lateral Sclerosis. NeuroSci 2021, 2, 120-134. [CrossRef]

19. Bellou, V.; Belbasis, L.; Tzoulaki, I.; Evangelou, E.; Ioannidis, J.P.A. Environmental Risk Factors and Parkinson's Disease: An Umbrella Review of Meta-Analyses. Parkinsonism Relat. Disord. 2016, 23, 1-9. [CrossRef] [PubMed]

20. Verhaar, B.J.H.; de Leeuw, F.A.; Doorduijn, A.S.; Fieldhouse, J.L.P.; van de Rest, O.; Teunissen, C.E.; van Berckel, B.N.M.; Barkhof, F.; Visser, M.; de van der Schueren, M.A.E.; et al. Nutritional Status and Structural Brain Changes in Alzheimer's Disease: The NUDAD Project. Alzheimers Dement. Diagn. Assess. Dis. Monit. 2020, 12, e12063. [CrossRef]

21. Depommier, C.; Everard, A.; Druart, C.; Plovier, H.; Van Hul, M.; Vieira-Silva, S.; Falony, G.; Raes, J.; Maiter, D.; Delzenne, N.M.; et al. Supplementation with Akkermansia Muciniphila in Overweight and Obese Human Volunteers: A Proof-of-Concept Exploratory Study. Nat. Med. 2019, 25, 1096-1103. [CrossRef]

22. Blacher, E.; Bashiardes, S.; Shapiro, H.; Rothschild, D.; Mor, U.; Dori-Bachash, M.; Kleimeyer, C.; Moresi, C.; Harnik, Y.; Zur, M.; et al. Potential Roles of Gut Microbiome and Metabolites in Modulating ALS in Mice. Nature 2019, 572, 474-480. [CrossRef]

23. Cryan, J.F.; O’Riordan, K.J.; Sandhu, K.; Peterson, V.; Dinan, T.G. The Gut Microbiome in Neurological Disorders. Lancet Neurol. 2020, 19, 179-194. [CrossRef]

24. Quigley, E.M.M. Microbiota-Brain-Gut Axis and Neurodegenerative Diseases. Curr. Neurol. Neurosci. Rep. 2017, 17, 94. [CrossRef]

25. Klingelhoefer, L.; Reichmann, H. Pathogenesis of Parkinson Disease-the Gut-Brain Axis and Environmental Factors. Nat. Rev. Neurol. 2015, 11, 625-636. [CrossRef] [PubMed]

26. Cattaneo, A.; Cattane, N.; Galluzzi, S.; Provasi, S.; Lopizzo, N.; Festari, C.; Ferrari, C.; Guerra, U.P.; Paghera, B.; Muscio, C.; et al. Association of Brain Amyloidosis with Pro-Inflammatory Gut Bacterial Taxa and Peripheral Inflammation Markers in Cognitively Impaired Elderly. Neurobiol. Aging 2017, 49, 60-68. [CrossRef]

27. Cox, P.A.; Kostrzewa, R.M.; Guillemin, G.J. BMAA and Neurodegenerative Illness. Neurotox. Res. 2018, 3, 178-183. [CrossRef] [PubMed]

28. Fiore, M.F.; de Lima, S.T.; Carmichael, W.W.; McKinnie, S.M.K.; Chekan, J.R.; Moore, B.S. Guanitoxin, Re-Naming a Cyanobacterial Organophosphate Toxin. Harmful Algae 2020, 92, 101737. [CrossRef]

29. Buratti, F.M.; Manganelli, M.; Vichi, S.; Stefanelli, M.; Scardala, S.; Testai, E.; Funari, E. Cyanotoxins: Producing Organisms, Occurrence, Toxicity, Mechanism of Action and Human Health Toxicological Risk Evaluation. Arch Toxicol. 2017, 91, 1049-1130. [CrossRef] [PubMed]

30. Plaas, H.E.; Paerl, H.W. Toxic Cyanobacteria: A Growing Threat to Water and Air Quality. Environ. Sci. Technol. 2021, 55, 44-64. [CrossRef]

31. Berntzon, L.; Ronnevi, L.O.; Bergman, B.; Eriksson, J. Detection of BMAA in the Human Central Nervous System. Neuroscience 2015, 292, 137-147. [CrossRef]

32. Dunlop, R.A.; Banack, S.A.; Bishop, E.S.; Metcalf, J.S.; Murch, S.J.; Davis, D.A.; Stommel, E.W.; Karlsson, A.; Bribetto, A.; Chatziefthimiou, A.; et al. Is Exposure to BMAA a Risk Factor for Neurodegenerative Diseases? A Response to a Critical Review of the BMAA Hypothesis. Neurotox. Res. 2021, 39, 81-106. [CrossRef]

33. Brooks, B.W.; Lazorchak, J.M.; Howard, M.D.; Johnson, M.V.; Morton, S.L.; Perkins, D.A.; Reavie, E.D.; Scott, G.I.; Smith, S.A.; Steevens, J.A. Are Harmful Algal Blooms Becoming the Greatest Inland Water Quality Threat to Public Health and Aquatic Ecosystems? Environ. Toxicol. Chem. 2016, 35, 6-13. [CrossRef] 
34. Anderson, D.M.; Fensin, E.; Gobler, C.J.; Hoeglund, A.E.; Hubbard, K.A.; Kulis, D.M.; Landsberg, J.H.; Lefebvre, K.A.; Provoost, P.; Richlen, M.L.; et al. Marine Harmful Algal Blooms (HABs) in the United States: History, Current Status and Future Trends. Harmful Algae 2021, 102, 101975. [CrossRef]

35. Carpenter, S.R.; Caraco, N.F.; Correll, D.L.; Howarth, R.W.; Sharpley, A.N.; Smith, V.H. Nonpoint Pollution of Surface Waters with Phosphorus and Nitrogen. Ecol. Appl. 1998, 8, 559-568. [CrossRef]

36. Smith, V.H.; Tilman, G.D.; Nekola, J.C. Eutrophication: Impacts of Excess Nutrient Inputs on Freshwater, Marine, and Terrestrial Ecosystems. Environ. Pollut. 1999, 100, 179-196. [CrossRef]

37. Dodds, W.K.; Bouska, W.W.; Eitzmann, J.L.; Pilger, T.J.; Pitts, K.L.; Riley, A.J.; Schloesser, J.T.; Thornbrugh, D.J. Eutrophication of U.S. Freshwaters: Analysis of Potential Economic Damages. Environ. Sci. Technol. 2009, 43, 12-19. [CrossRef]

38. Assmy, P.; Smetacek, V. Algal Blooms. In Encyclopedia of Microbiology; Elsevier: New York, NY, USA, 2009; pp. 27-41. ISBN 978-0-12-373944-5.

39. Paerl, H.W.; Otten, T.G. Harmful Cyanobacterial Blooms: Causes, Consequences, and Controls. Microb. Ecol. 2013, 65, 995-1010. [CrossRef]

40. Merel, S.; Walker, D.; Chicana, R.; Snyder, S.; Baurès, E.; Thomas, O. State of Knowledge and Concerns on Cyanobacterial Blooms and Cyanotoxins. Environ. Int. 2013, 59, 303-327. [CrossRef] [PubMed]

41. Jørgensen, S.E.; International Lake Environment Committee and United Nations Environmental Programme. Lakes and Reservoirs. Volume 3, Water Quality: The Impact of Eutrophication; UNEP-IETC/ILEC. 2001. Available online: https://www.ilec.or.jp/wpcontent/uploads/pub/Vol.3.pdf (accessed on 2 August 2021).

42. Padedda, B.M.; Sechi, N.; Lai, G.G.; Mariani, M.A.; Pulina, S.; Sarria, M.; Satta, C.T.; Virdis, T.; Buscarinu, P.; Lugliè, A. Consequences of Eutrophication in the Management of Water Resources in Mediterranean Reservoirs: A Case Study of Lake Cedrino (Sardinia, Italy). Glob. Ecol. Conserv. 2017, 12, 21-35. [CrossRef]

43. Mariani, M.A.; Padedda, B.M.; Kastovsky, J.; Buscarinu, P.; Sechi, N.; Virdis, T.; Luglie, A. Effects of Trophic Status on Microcystin Production and the Dominance of Cyanobacteria in the Phytoplankton Assemblage of Mediterranean Reservoirs. Sci. Rep. 2015, 5, 17964. [CrossRef] [PubMed]

44. Mariani, M.A.; Lai, G.G.; Padedda, B.M.; Pulina, S.; Sechi, N.; Virdis, T.; Lugliè, A. Long-Term Ecological Studies on Phytoplankton in Mediterranean Reservoirs: A Case Study from Sardinia (Italy). Inland Waters 2015, 5, 339-354. [CrossRef]

45. Oliver, R.; Ganf, G. Freshwater blooms. In The Ecology of Cyanobacteria; Kluwer Academic Publishers: Dordrecht, The Netherland, 2000; pp. 149-194.

46. Schindler, D.; Hecky, R.; Findlay, D.; Stainton, M.; Parker, B.; Paterson, M.; Beaty, K.; Lyng, M.; Kasian, S. Eutrophication of Lakes Cannot Be Controlled by Reducing Nitrogen Input: Results of a 37-Year Whole-Ecosystem Experiment I PNAS. Available online: https:/ / www.pnas.org/content/105/32/11254 (accessed on 29 July 2021).

47. Padedda, B.M.; Lugliè, A.; Ceccherelli, G.; Trebini, F.; Sechi, N. Nutrient-Flux Evaluation by the LOICZ Biogeochemical Model in Mediterranean Lagoons: The Case of Cabras Lagoon (Central-Western Sardinia). Chem. Ecol. 2010, 26, 147-162. [CrossRef]

48. Seitzinger, S.P.; Kroeze, C. Global Distribution of Nitrous Oxide Production and N Inputs in Freshwater and Coastal Marine Ecosystems. Glob. Biogeochem. Cycles 1998, 12, 93-113. [CrossRef]

49. Van Drecht, G.; Bouwman, A.F.; Knoop, J.M.; Beusen, A.H.W.; Meinardi, C.R. Global Modeling of the Fate of Nitrogen from Point and Nonpoint Sources in Soils, Groundwater, and Surface Water. Glob. Biogeochem. Cycles 2003, 17. [CrossRef]

50. Tilman, D. Resource Competition between Plankton Algae: An Experimental and Theoretical Approach. Ecology 1977, 58, 338-348. [CrossRef]

51. Smayda, T.J. Harmful Algal Blooms: Their Ecophysiology and General Relevance to Phytoplankton Blooms in the Sea. Limnol. Oceanogr. 1997, 42, 1137-1153. [CrossRef]

52. Smayda, T.; Graneli, E.; Sundstrom, B.; Edler, L.; Anderson, D.; Smayda, T. Novel and Nuisance Phytoplankton Blooms in the Sea: Evidence for a Global Epidemic. Toxic Mar. Phytoplankton 1990, 1, $29-40$.

53. Anderson, D.M.; Glibert, P.M.; Burkholder, J.M. Harmful Algal Blooms and Eutrophication: Nutrient Sources, Composition, and Consequences. Estuaries 2002, 25, 704-726. [CrossRef]

54. Glibert, P.M.; Harrison, J.; Heil, C.; Seitzinger, S. Escalating Worldwide Use of Urea-A Global Change Contributing to Coastal Eutrophication. Biogeochemistry 2006, 77, 441-463. [CrossRef]

55. Burkholder, J.M.; Glibert, P.M.; Skelton, H.M. Mixotrophy, a Major Mode of Nutrition for Harmful Algal Species in Eutrophic Waters. Harmful Algae 2008, 8, 77-93. [CrossRef]

56. Fadda, A.; Marková, S.; Kotlík, P.; Lugliè, A.; Padedda, B.; Buscarinu, P.; Sechi, N.; Manca, M. First Record of Planktonic Crustaceans in Sardinian Reservoirs. Biologia 2011, 66, 856-865. [CrossRef]

57. Padedda, B.M.; Sechi, N.; Lai, G.G.; Mariani, M.A.; Pulina, S.; Satta, C.T.; Bazzoni, A.M.; Virdis, T.; Buscarinu, P.; Lugliè, A. A Fast-Response Methodological Approach to Assessing and Managing Nutrient Loads in Eutrophic Mediterranean Reservoirs. Ecol. Eng. 2015, 85, 47-55. [CrossRef]

58. Zingone, A.; Escalera, L.; Aligizaki, K.; Fernández-Tejedor, M.; Ismael, A.; Montresor, M.; Mozetič, P.; Taş, S.; Totti, C. Toxic Marine Microalgae and Noxious Blooms in the Mediterranean Sea: A Contribution to the Global HAB Status Report. Harmful Algae 2021, 102, 101843. [CrossRef] [PubMed]

59. Nunes-Costa, D.; Magalhães, J.D.; G-Fernandes, M.; Cardoso, S.M.; Empadinhas, N. Microbial BMAA and the Pathway for Parkinson's Disease Neurodegeneration. Front. Aging Neurosci. 2020, 12, 26. [CrossRef] [PubMed] 
60. Spencer, P.S.; Palmer, V.S.; Kisby, G.E. Cycad $\beta$-N-Methylamino-L-Alanine (BMAA), Methylazoxymethanol, Genotoxicity, and Neurodegeneration. Toxicon 2018, 155, 49-50. [CrossRef] [PubMed]

61. Luglie, A.; Pulina, S.; Bruno, M.; Padedda, B.M.; Satta, C.T.; Sechi, N. Marine Toxins and Climate Change: The Case of PSP from Cyanobacteria in Coastal Lagoons. In Phycotoxins: Chemistry and Biochemistry, 2nd ed.; Botana, L.M., Alfonso, A., Eds.; Wiley-Blackwell: Malden, MA, USA, 2015; ISBN 978-1-118-50033-0.

62. Rastogi, R.P.; Madamwar, D.; Incharoensakdi, A. Bloom Dynamics of Cyanobacteria and Their Toxins: Environmental Health Impacts and Mitigation Strategies. Front. Microbiol. 2015, 6, 1254. [CrossRef]

63. Sha, J.; Xiong, H.; Li, C.; Lu, Z.; Zhang, J.; Zhong, H.; Zhang, W.; Yan, B. Harmful Algal Blooms and Their Eco-Environmental Indication. Chemosphere 2021, 274, 129912. [CrossRef]

64. Moreira, C.; Vasconcelos, V.; Antunes, A. Phylogeny and Biogeography of Cyanobacteria and Their Produced Toxins. Mar. Drugs 2013, 11, 4350-4369. [CrossRef]

65. Paerl, H.W.; Huisman, J. Climate. Blooms like It Hot. Science 2008, 320, 57-58. [CrossRef]

66. O'Neill, K.; Musgrave, I.F.; Humpage, A. Extended Low-Dose Exposure to Saxitoxin Inhibits Neurite Outgrowth in Model Neuronal Cells. Basic Clin. Pharmacol. Toxicol. 2017, 120, 390-397. [CrossRef]

67. Drobac, D.; Tokodi, N.; Simeunovic, J.; Baltic, V.; Stanic, D.; Svircev, Z. Human Exposure to Cyanotoxins and Their Effects on Health. Arh. Hig. Rada Toksikol. 2013, 64, 119-130. [CrossRef]

68. Hernandez, B.Y.; Zhu, X.; Sotto, P.; Paulino, Y. Oral Exposure to Environmental Cyanobacteria Toxins: Implications for Cancer Risk. Environ. Int. 2021, 148, 106381. [CrossRef]

69. Rutkowska, M.; Płotka-Wasylka, J.; Majchrzak, T.; Wojnowski, W.; Mazur-Marzec, H.; Namieśnik, J. Recent Trends in Determination of Neurotoxins in Aquatic Environmental Samples. TrAC Trends Anal. Chem. 2019, 112, 112-122. [CrossRef]

70. Wiese, M.; D’Agostino, P.M.; Mihali, T.K.; Moffitt, M.C.; Neilan, B.A. Neurotoxic Alkaloids: Saxitoxin and Its Analogs. Mar. Drugs 2010, 8, 2185-2211. [CrossRef]

71. Watanabe, R.; Kanamori, M.; Yoshida, H.; Okumura, Y.; Uchida, H.; Matsushima, R.; Oikawa, H.; Suzuki, T. Development of Ultra-Performance Liquid Chromatography with Post-Column Fluorescent Derivatization for the Rapid Detection of Saxitoxin Analogues and Analysis of Bivalve Monitoring Samples. Toxins 2019, 11, 573. [CrossRef] [PubMed]

72. Batoréu, M.C.C.; Dias, E.; Pereira, P.; Franca, S. Risk of Human Exposure to Paralytic Toxins of Algal Origin. Environ. Toxicol. Pharmacol. 2005, 19, 401-406. [CrossRef] [PubMed]

73. Shen, H.; Li, Z.; Jiang, Y.; Pan, X.; Wu, J.; Cristofori-Armstrong, B.; Smith, J.J.; Chin, Y.K.Y.; Lei, J.; Zhou, Q.; et al. Structural Basis for the Modulation of Voltage-Gated Sodium Channels by Animal Toxins. Science 2018, 362. [CrossRef]

74. Cervantes Cianca, R.C.; Pallares, M.A.; Durán Barbosa, R.; Vidal Adan, L.; Leão Martins, J.M.; Gago-Martínez, A. Application of Precolumn Oxidation HPLC Method with Fluorescence Detection to Evaluate Saxitoxin Levels in Discrete Brain Regions of Rats. Toxic. Off. J. Int. Soc. Toxinol. 2007, 49, 89-99. [CrossRef] [PubMed]

75. Subramanian, N.; Wetzel, A.; Dombert, B.; Yadav, P.; Havlicek, S.; Jablonka, S.; Nassar, M.A.; Blum, R.; Sendtner, M. Role of $\mathrm{Na}(\mathrm{v}) 1.9$ in Activity-Dependent Axon Growth in Motoneurons. Hum. Mol. Genet. 2012, 21, 3655-3667. [CrossRef]

76. Da Silva, C.A.; de Morais, E.C.P.; Costa, M.D.M.; Ribas, J.L.C.; Guiloski, I.C.; Ramsdorf, W.A.; Zanata, S.M.; Cestari, M.M.; Ribeiro, C.A.O.; Magalhães, V.F.; et al. Saxitoxins Induce Cytotoxicity, Genotoxicity and Oxidative Stress in Teleost Neurons in Vitro. Toxic. Off. J. Int. Soc. Toxinol. 2014, 86, 8-15. [CrossRef]

77. Zhou, Z.; Tang, X.; Chen, H.; Wang, Y. Comparative Studies of Saxitoxin (STX) -Induced Cytotoxicity in Neuro-2a and RTG-2 Cell Lines: An Explanation with Respect to Changes in ROS. Chemosphere 2018, 192, 66-74. [CrossRef]

78. D’Mello, F.; Braidy, N.; Marcal, H.; Guillemin, G.; Rossi, F.; Chinian, M.; Laurent, D.; Teo, C.; Neilan, B.A. Cytotoxic Effects of Environmental Toxins on Human Glial Cells. Neurotox. Res. 2017, 31, 245-258. [CrossRef]

79. Chen, G.; Jia, Z.; Wang, L.; Hu, T. Effect of Acute Exposure of Saxitoxin on Development of Zebrafish Embryos (Danio Rerio). Environ. Res. 2020, 185, 109432. [CrossRef] [PubMed]

80. Lima-Filho, C.M.; Nogaroli, L.; Hedin-Pereira, C.; Azevedo, S.M.F.O.; Soares, R.M. Effects of Saxitoxins Exposure on Oligodendrocyte Development in Mouse Neonates. Toxicon 2020, 188, 89-94. [CrossRef] [PubMed]

81. L'Herondelle, K.; Talagas, M.; Mignen, O.; Misery, L.; Le Garrec, R. Neurological Disturbances of Ciguatera Poisoning: Clinical Features and Pathophysiological Basis. Cells 2020, 9, 2291. [CrossRef] [PubMed]

82. Vilarino, N.; Louzao, M.C.; Abal, P.; Cagide, E.; Carrera, C.; Vieytes, M.R.; Botana, L.M. Human Poisoning from Marine Toxins: Unknowns for Optimal Consumer Protection. Toxins 2018, 10, 324. [CrossRef]

83. Au, N.P.; Kumar, G.; Asthana, P.; Tin, C.; Mak, Y.L.; Chan, L.L.; Lam, P.K.; Ma, C.H. Ciguatoxin Reduces Regenerative Capacity of Axotomized Peripheral Neurons and Delays Functional Recovery in Pre-Exposed Mice after Peripheral Nerve Injury. Sci. Rep. 2016, 6, 26809. [CrossRef]

84. Inserra, M.C.; Israel, M.R.; Caldwell, A.; Castro, J.; Deuis, J.R.; Harrington, A.M.; Keramidas, A.; Garcia-Caraballo, S.; Maddern, J.; Erickson, A.; et al. Multiple Sodium Channel Isoforms Mediate the Pathological Effects of Pacific Ciguatoxin-1. Sci. Rep. 2017, 7, 42810. [CrossRef] [PubMed]

85. Touska, F.; Sattler, S.; Malsch, P.; Lewis, R.J.; Reeh, P.W.; Zimmermann, K. Ciguatoxins Evoke Potent CGRP Release by Activation of Voltage-Gated Sodium Channel Subtypes NaV1.9, NaV1.7 and NaV1.1. Mar. Drugs 2017, 15, 269. [CrossRef]

86. Russell, F.A.; King, R.; Smillie, S.-J.; Kodji, X.; Brain, S.D. Calcitonin Gene-Related Peptide: Physiology and Pathophysiology. Physiol. Rev. 2014, 94, 1099-1142. [CrossRef] [PubMed] 
87. Ringer, C.; Tune, S.; Bertoune, M.A.; Schwarzbach, H.; Tsujikawa, K.; Weihe, E.; Schütz, B. Disruption of Calcitonin Gene-Related Peptide Signaling Accelerates Muscle Denervation and Dampens Cytotoxic Neuroinflammation in SOD1 Mutant Mice. Cell. Mol. Life Sci. CMLS 2017, 74, 339-358. [CrossRef]

88. Ratliff, W.A.; Saykally, J.N.; Kane, M.J.; Citron, B.A. Neuromuscular Junction Morphology and Gene Dysregulation in the Wobbler Model of Spinal Neurodegeneration. J. Mol. Neurosci. MN 2018, 66, 114-120. [CrossRef]

89. Morabito, S.; Silvestro, S.; Faggio, C. How the Marine Biotoxins Affect Human Health. Nat. Prod. Res. 2018, 32, 621-631. [CrossRef]

90. Rubiolo, J.A.; Vale, C.; Boente-Juncal, A.; Hirama, M.; Yamashita, S.; Camiña, M.; Vieytes, M.R.; Botana, L.M. Transcriptomic Analysis of Ciguatoxin-Induced Changes in Gene Expression in Primary Cultures of Mice Cortical Neurons. Toxins 2018, 10, 192. [CrossRef]

91. Coccini, T.; Caloni, F.; De Simone, U. Human Neuronal Cell Based Assay: A New in Vitro Model for Toxicity Evaluation of Ciguatoxin. Environ. Toxicol. Pharmacol. 2017, 52, 200-213. [CrossRef]

92. Alonso, E.; Vieira, A.C.; Rodriguez, I.; Alvariño, R.; Gegunde, S.; Fuwa, H.; Suga, Y.; Sasaki, M.; Alfonso, A.; Cifuentes, J.M.; et al. Tetracyclic Truncated Analogue of the Marine Toxin Gambierol Modifies NMDA, Tau, and Amyloid $\beta$ Expression in Mice Brains: Implications in AD Pathology. ACS Chem. Neurosci. 2017, 8, 1358-1367. [CrossRef] [PubMed]

93. Vetter, I.; Touska, F.; Hess, A.; Hinsbey, R.; Sattler, S.; Lampert, A.; Sergejeva, M.; Sharov, A.; Collins, L.S.; Eberhardt, M.; et al. Ciguatoxins Activate Specific Cold Pain Pathways to Elicit Burning Pain from Cooling. EMBO J. 2012, 31, 3795-3808. [CrossRef]

94. Asthana, P.; Zhang, N.; Kumar, G.; Chine, V.B.; Singh, K.K.; Mak, Y.L.; Chan, L.L.; Lam, P.K.S.; Ma, C.H.E. Pacific Ciguatoxin Induces Excitotoxicity and Neurodegeneration in the Motor Cortex Via Caspase 3 Activation: Implication for Irreversible Motor Deficit. Mol. Neurobiol. 2018, 55, 6769-6787. [CrossRef] [PubMed]

95. Du, X.; Liu, H.; Yuan, L.; Wang, Y.; Ma, Y.; Wang, R.; Chen, X.; Losiewicz, M.D.; Guo, H.; Zhang, H. The Diversity of Cyanobacterial Toxins on Structural Characterization, Distribution and Identification: A Systematic Review. Toxins 2019, 11, 530. [CrossRef] [PubMed]

96. Spivak, C.E.; Witkop, B.; Albuquerque, E.X. Anatoxin-a: A Novel, Potent Agonist at the Nicotinic Receptor. Mol. Pharmacol. 1980, 18, 384-394.

97. Posadas, I.; López-Hernández, B.; Ceña, V. Nicotinic Receptors in Neurodegeneration. Curr. Neuropharmacol. 2013, 11, 298-314. [CrossRef]

98. Koukouli, F.; Changeux, J.-P. Do Nicotinic Receptors Modulate High-Order Cognitive Processing? Trends Neurosci. 2020, 43, 550-564. [CrossRef]

99. Moss, D.E. Improving Anti-Neurodegenerative Benefits of Acetylcholinesterase Inhibitors in Alzheimer's Disease: Are Irreversible Inhibitors the Future? Int. J. Mol. Sci. 2020, 21, 3438. [CrossRef] [PubMed]

100. Takser, L.; Benachour, N.; Husk, B.; Cabana, H.; Gris, D. Cyanotoxins at Low Doses Induce Apoptosis and Inflammatory Effects in Murine Brain Cells: Potential Implications for Neurodegenerative Diseases. Toxicol. Rep. 2016, 3, 180-189. [CrossRef] [PubMed]

101. Nunn, P.B. 50 Years of Research on $\alpha$-Amino- $\beta$-Methylaminopropionic Acid ( $\beta$-Methylaminoalanine). Phytochemistry 2017, 144, 271-281. [CrossRef] [PubMed]

102. Chernoff, N.; Hill, D.J.; Diggs, D.L.; Faison, B.D.; Francis, B.M.; Lang, J.R.; Larue, M.M.; Le, T.-T.; Loftin, K.A.; Lugo, J.N.; et al. A Critical Review of the Postulated Role of the Non-Essential Amino Acid, $\beta$-N-Methylamino-L-Alanine, in Neurodegenerative Disease in Humans. J. Toxicol. Environ. Health Part B 2017, 20, 183-229. [CrossRef] [PubMed]

103. Pablo, J.; Banack, S.A.; Cox, P.A.; Johnson, T.E.; Papapetropoulos, S.; Bradley, W.G.; Buck, A.; Mash, D.C. Cyanobacterial Neurotoxin BMAA in ALS and Alzheimer's Disease. Acta Neurol. Scand. 2009, 120, 216-225. [CrossRef]

104. Spencer, P.S.; Nunn, P.B.; Hugon, J.; Ludolph, A.C.; Robertson, R.C. Guam Amyotrophic Lateral Sclerosis-Parkinsonism- Dementia Linked to a Plant Excitant Neurotoxin. Science 1987, 237, 517-522. [CrossRef]

105. Cox, P.A.; Banack, S.A.; Murch, S.J.; Rasmussen, U.; Tien, G.; Bidigare, R.R.; Metcalf, J.S.; Morrison, L.F.; Codd, G.A.; Bergman, B. Diverse Taxa of Cyanobacteria Produce Beta-N-Methylamino-L-Alanine, a Neurotoxic Amino Acid. Proc. Natl. Acad. Sci. USA 2005, 102, 5074-5078. [CrossRef]

106. Cox, P.A.; Banack, S.A.; Murch, S.J. Biomagnification of Cyanobacterial Neurotoxins and Neurodegenerative Disease among the Chamorro People of Guam. Proc. Natl. Acad. Sci. USA 2003, 100, 13380-13383. [CrossRef]

107. Lage, S.; Annadotter, H.; Rasmussen, U.; Rydberg, S. Biotransfer of $\beta$-N-Methylamino-L-Alanine (BMAA) in a Eutrophicated Freshwater Lake. Mar. Drugs 2015, 13, 1185-1201. [CrossRef]

108. Samardzic, K.; Steele, J.R.; Violi, J.P.; Colville, A.; Mitrovic, S.M.; Rodgers, K.J. Toxicity and Bioaccumulation of Two Non-Protein Amino Acids Synthesised by Cyanobacteria, $\beta$-N-Methylamino-L-Alanine (BMAA) and 2,4-Diaminobutyric Acid (DAB), on a Crop Plant. Ecotoxicol. Environ. Saf. 2021, 208, 111515. [CrossRef] [PubMed]

109. Xie, X.; Basile, M.; Mash, D.C. Cerebral Uptake and Protein Incorporation of Cyanobacterial Toxin $\beta$-N-Methylamino-L-Alanine. Neuroreport 2013, 24, 779-784. [CrossRef] [PubMed]

110. Murch, S.J.; Cox, P.A.; Banack, S.A.; Steele, J.C.; Sacks, O.W. Occurrence of Beta-Methylamino-l-Alanine (BMAA) in ALS/PDC Patients from Guam. Acta Neurol. Scand. 2004, 110, 267-269. [CrossRef] [PubMed]

111. Bradley, W.G.; Mash, D.C. Beyond Guam: The Cyanobacteria/BMAA Hypothesis of the Cause of ALS and Other Neurodegenerative Diseases. Amyotroph. Lateral Scler. 2009, 10 (Suppl. 2), 7-20. [CrossRef] [PubMed] 
112. Dunlop, R.A.; Guillemin, G.J. The Cyanotoxin and Non-Protein Amino Acid $\beta$-Methylamino-L-Alanine (L-BMAA) in the Food Chain: Incorporation into Proteins and Its Impact on Human Health. Neurotox. Res. 2019, 36, 602-611. [CrossRef] [PubMed]

113. Lobner, D. Mechanisms of Beta-N-Methylamino-L-Alanine Induced Neurotoxicity. Amyotroph. Lateral Scler. 2009, 10 (Suppl. 2), 56-60. [CrossRef]

114. Chiu, A.S.; Gehringer, M.M.; Braidy, N.; Guillemin, G.J.; Welch, J.H.; Neilan, B.A. Excitotoxic Potential of the Cyanotoxin $\beta$-Methyl-Amino-l-Alanine (BMAA) in Primary Human Neurons. Toxicon 2012, 60, 1159-1165. [CrossRef]

115. Weiss, J.H.; Choi, D.W. Beta-N-Methylamino-L-Alanine Neurotoxicity: Requirement for Bicarbonate as a Cofactor. Sci. New Ser. 1988, 241, 973-975. [CrossRef]

116. Delcourt, N.; Claudepierre, T.; Maignien, T.; Arnich, N.; Mattei, C. Cellular and Molecular Aspects of the $\beta-N-M e t h y l a m i n o-1-$ Alanine (BMAA) Mode of Action within the Neurodegenerative Pathway: Facts and Controversy. Toxins 2017, 10, 6. [CrossRef]

117. Hardiman, O.; Al-Chalabi, A.; Chio, A.; Corr, E.M.; Logroscino, G.; Robberecht, W.; Shaw, P.J.; Simmons, Z.; van den Berg, L.H. Amyotrophic Lateral Sclerosis. Nat. Rev. Primer 2017, 3, 17071. [CrossRef]

118. Liu, X.; Rush, T.; Zapata, J.; Lobner, D. $\beta$-N-Methylamino-l-Alanine Induces Oxidative Stress and Glutamate Release through Action on System Xc-. Exp. Neurol. 2009, 217, 429-433. [CrossRef]

119. Dunlop, R.A.; Cox, P.A.; Banack, S.A.; Rodgers, K.J. The Non-Protein Amino Acid BMAA Is Misincorporated into Human Proteins in Place of 1-Serine Causing Protein Misfolding and Aggregation. PLoS ONE 2013, 8, e75376. [CrossRef]

120. Glover, W.B.; Mash, D.C.; Murch, S.J. The Natural Non-Protein Amino Acid N- $\beta$-Methylamino-l-Alanine (BMAA) Is Incorporated into Protein during Synthesis. Amino Acids 2014, 46, 2553-2559. [CrossRef] [PubMed]

121. Sanna, S.; Esposito, S.; Masala, A.; Sini, P.; Nieddu, G.; Galioto, M.; Fais, M.; Iaccarino, C.; Cestra, G.; Crosio, C. HDAC1 Inhibition Ameliorates TDP-43-Induced Cell Death in Vitro and in Vivo. Cell Death Dis. 2020, 11, 369. [CrossRef]

122. Jo, M.; Lee, S.; Jeon, Y.-M.; Kim, S.; Kwon, Y.; Kim, H.-J. The Role of TDP-43 Propagation in Neurodegenerative Diseases: Integrating Insights from Clinical and Experimental Studies. Exp. Mol. Med. 2020, 52, 1652-1662. [CrossRef] [PubMed]

123. Prasad, A.; Bharathi, V.; Sivalingam, V.; Girdhar, A.; Patel, B.K. Molecular Mechanisms of TDP-43 Misfolding and Pathology in Amyotrophic Lateral Sclerosis. Front. Mol. Neurosci. 2019, 12, 25. [CrossRef]

124. De Munck, E.; Munoz-Saez, E.; Miguel, B.G.; Solas, M.T.; Ojeda, I.; Martinez, A.; Gil, C.; Arahuetes, R.M. Beta-N-Methylamino1-Alanine Causes Neurological and Pathological Phenotypes Mimicking Amyotrophic Lateral Sclerosis (ALS): The First Step towards an Experimental Model for Sporadic ALS. Environ. Toxicol. Pharmacol. 2013, 36, 243-255. [CrossRef]

125. Scott, L.; Downing, T. Dose-Dependent Adult Neurodegeneration in a Rat Model After Neonatal Exposure to $\beta$-N-Methylamino1-Alanine. Neurotox. Res. 2019, 35, 711-723. [CrossRef]

126. Yin, H.Z.; Yu, S.; Hsu, C.-I.; Liu, J.; Acab, A.; Wu, R.; Tao, A.; Chiang, B.J.; Weiss, J.H. Intrathecal Infusion of BMAA Induces Selective Motor Neuron Damage and Astrogliosis in the Ventral Horn of the Spinal Cord. Exp. Neurol. 2014, 261, 1-9. [CrossRef]

127. Ritson, G.P.; Custer, S.K.; Freibaum, B.D.; Guinto, J.B.; Geffel, D.; Moore, J.; Tang, W.; Winton, M.J.; Neumann, M.; Trojanowski, J.Q.; et al. TDP-43 Mediates Degeneration in a Novel Drosophila Model of Disease Caused by Mutations in VCP/P97. J. Neurosci. 2010, 30, 7729-7739. [CrossRef]

128. Martin, R.M.; Bereman, M.S.; Marsden, K.C. BMAA and MCLR Interact to Modulate Behavior and Exacerbate Molecular Changes Related to Neurodegeneration in Larval Zebrafish. Toxicol. Sci. Off. J. Soc. Toxicol. 2020, 179, 251-261. [CrossRef]

129. Okle, O.; Stemmer, K.; Deschl, U.; Dietrich, D.R. L-BMAA Induced ER Stress and Enhanced Caspase 12 Cleavage in Human Neuroblastoma SH-SY5Y Cells at Low Nonexcitotoxic Concentrations. Toxicol. Sci. 2013, 131, 217-224. [CrossRef]

130. Beri, J.; Nash, T.; Martin, R.M.; Bereman, M.S. Exposure to BMAA Mirrors Molecular Processes Linked to Neurodegenerative Disease. PROTEOMICS 2017, 17, 1700161. [CrossRef]

131. Ma, Q. Role of Nrf2 in Oxidative Stress and Toxicity. Annu. Rev. Pharmacol. Toxicol. 2013, 53, 401-426. [CrossRef] [PubMed]

132. Dunys, J.; Duplan, E.; Checler, F. The Transcription Factor X-Box Binding Protein-1 in Neurodegenerative Diseases. Mol. Neurodegener. 2014, 9, 35. [CrossRef] [PubMed]

133. Pierozan, P.; Cattani, D.; Karlsson, O. Hippocampal Neural Stem Cells Are More Susceptible to the Neurotoxin BMAA than Primary Neurons: Effects on Apoptosis, Cellular Differentiation, Neurite Outgrowth, and DNA Methylation. Cell Death Dis. 2020, 11, 910. [CrossRef]

134. Greene, L.A.; Tischler, A.S. Establishment of a Noradrenergic Clonal Line of Rat Adrenal Pheochromocytoma Cells Which Respond to Nerve Growth Factor. Proc. Natl. Acad. Sci. USA 1976, 73, 2424-2428. [CrossRef]

135. Lee, M.; McGeer, P.L. Weak BMAA Toxicity Compares with That of the Dietary Supplement Beta-Alanine. Neurobiol. Aging 2012, 33, 1440-1447. [CrossRef]

136. Munoz-Saez, E.; de Munck Garcia, E.; Arahuetes Portero, R.M.; Vicente, F.; Ortiz-Lopez, F.J.; Cantizani, J.; Gomez Miguel, B. Neuroprotective Role of Sphingosine-1-Phosphate in L-BMAA Treated Neuroblastoma Cells (SH-SY5Y). Neurosci. Lett. 2015, 593, 83-89. [CrossRef] [PubMed]

137. Main, B.J.; Dunlop, R.A.; Rodgers, K.J. The Use of L-Serine to Prevent Beta-Methylamino-L-Alanine (BMAA)-Induced Proteotoxic Stress in Vitro. Toxicon 2016, 109, 7-12. [CrossRef]

138. Engskog, M.K.R.; Ersson, L.; Haglöf, J.; Arvidsson, T.; Pettersson, C.; Brittebo, E. $\beta$-N-Methylamino-l-Alanine (BMAA) Perturbs Alanine, Aspartate and Glutamate Metabolism Pathways in Human Neuroblastoma Cells as Determined by Metabolic Profiling. Amino Acids 2017, 49, 905-919. [CrossRef] [PubMed] 
139. Dunlop, R.A.; Carney, J.M. Mechanisms of L-Serine-Mediated Neuroprotection Include Selective Activation of Lysosomal Cathepsins B and L. Neurotox. Res. 2020, 39, 17-26. [CrossRef]

140. Silva, D.F.; Candeias, E.; Esteves, A.R.; Magalhães, J.D.; Ferreira, I.L.; Nunes-Costa, D.; Rego, A.C.; Empadinhas, N.; Cardoso, S.M. Microbial BMAA Elicits Mitochondrial Dysfunction, Innate Immunity Activation, and Alzheimer's Disease Features in Cortical Neurons. J. Neuroinflamm. 2020, 17, 332. [CrossRef]

141. Van Onselen, R.; Venables, L.; van de Venter, M.; Downing, T.G. $\beta$-N-Methylamino-L-Alanine Toxicity in PC12: Excitotoxicity vs. Misincorporation. Neurotox. Res. 2018, 33, 15-23. [CrossRef] [PubMed]

142. Soto, T.; Buzzi, E.D.; Rotstein, N.P.; German, O.L.; Politi, L.E. Damaging Effects of BMAA on Retina Neurons and Müller Glial Cells. Exp. Eye Res. 2021, 202, 108342. [CrossRef]

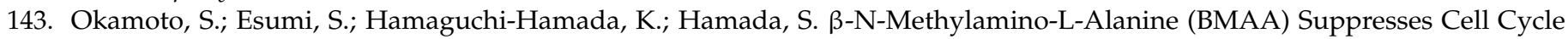
Progression of Non-Neuronal Cells. Sci. Rep. 2018, 8, 17995. [CrossRef]

144. Richter, K.E.; Mena, E.E. L-B-Methylaminoalanine Inhibits [3H]Glutamate Binding in the Presence of Bicarbonate Ions. Brain Res. 1989, 492, 385-388. [CrossRef]

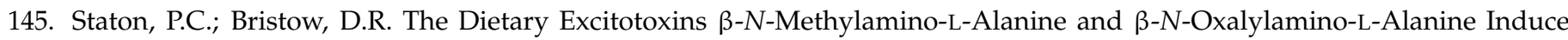
Necrotic- and Apoptotic-Like Death of Rat Cerebellar Granule Cells. J. Neurochem. 1997, 69, 1508-1518. [CrossRef] [PubMed]

146. Lobner, D.; Piana, P.M.T.; Salous, A.K.; Peoples, R.W. $\beta$-N-Methylamino-l-Alanine Enhances Neurotoxicity through Multiple Mechanisms. Neurobiol. Dis. 2007, 25, 360-366. [CrossRef]

147. Tan, V.X.; Mazzocco, C.; Varney, B.; Bodet, D.; Guillemin, T.A.; Bessede, A.; Guillemin, G.J. Detection of the Cyanotoxins L-BMAA Uptake and Accumulation in Primary Neurons and Astrocytes. Neurotox. Res. 2018, 33, 55-61. [CrossRef] [PubMed]

148. Tan, V.X.; Lassus, B.; Lim, C.K.; Tixador, P.; Courte, J.; Bessede, A.; Guillemin, G.J.; Peyrin, J.-M. Neurotoxicity of the Cyanotoxin BMAA Through Axonal Degeneration and Intercellular Spreading. Neurotox. Res. 2018, 33, 62-75. [CrossRef] [PubMed]

149. Johnson, H.E.; King, S.R.; Banack, S.A.; Webster, C.; Callanaupa, W.J.; Cox, P.A. Cyanobacteria (Nostoc Commune) Used as a Dietary Item in the Peruvian Highlands Produce the Neurotoxic Amino Acid BMAA. J. Ethnopharmacol. 2008, 118, 159-165. [CrossRef]

150. Backer, L.C.; McNeel, S.V.; Barber, T.; Kirkpatrick, B.; Williams, C.; Irvin, M.; Zhou, Y.; Johnson, T.B.; Nierenberg, K.; Aubel, M.; et al. Recreational Exposure to Microcystins during Algal Blooms in Two California Lakes. Toxic. Off. J. Int. Soc. Toxinol. 2010, 55, 909-921. [CrossRef]

151. Cox, P.A. BMAA, Neurodegeneration, and Neuroprotection. Neurotox. Res. 2021, 39, 1-5. [CrossRef]

152. Scott, L.L.; Downing, S.; Downing, T.G. The Evaluation of BMAA Inhalation as a Potential Exposure Route Using a Rat Model. Neurotox. Res. 2018, 33, 6-14. [CrossRef] [PubMed]

153. Levine, T.D.; Miller, R.G.; Bradley, W.G.; Moore, D.H.; Saperstein, D.S.; Flynn, L.E.; Katz, J.S.; Forshew, D.A.; Metcalf, J.S.; Banack, S.A.; et al. Phase I Clinical Trial of Safety of L-Serine for ALS Patients. Amyotroph. Lateral Scler. Front. Degener. 2017, 18, 107-111. [CrossRef] [PubMed]

154. Fridman, V.; Suriyanarayanan, S.; Novak, P.; David, W.; Macklin, E.A.; McKenna-Yasek, D.; Walsh, K.; Aziz-Bose, R.; Oaklander, A.L.; Brown, R.; et al. Randomized Trial of L-Serine in Patients with Hereditary Sensory and Autonomic Neuropathy Type 1. Neurology 2019, 92, e359-e370. [CrossRef]

155. Brenner, S.R. Blue-Green Algae or Cyanobacteria in the Intestinal Micro-Flora May Produce Neurotoxins Such as Beta-NMethylamino-L-Alanine (BMAA) Which May Be Related to Development of Amyotrophic Lateral Sclerosis, Alzheimer's Disease and Parkinson-Dementia-Complex in Humans and Equine Motor Neuron Disease in Horses. Med. Hypotheses 2013, 80, 103. [CrossRef]

156. Brenner, D.; Hiergeist, A.; Adis, C.; Mayer, B.; Gessner, A.; Ludolph, A.C.; Weishaupt, J.H. The Fecal Microbiome of ALS Patients. Neurobiol. Aging 2018, 61, 132-137. [CrossRef]

157. Ceppa, F.A.; Izzo, L.; Sardelli, L.; Raimondi, I.; Tunesi, M.; Albani, D.; Giordano, C. Human Gut-Microbiota Interaction in Neurodegenerative Disorders and Current Engineered Tools for Its Modeling. Front. Cell. Infect. Microbiol. 2020, $10,297$. [CrossRef] [PubMed]

158. Vascellari, S.; Palmas, V.; Melis, M.; Pisanu, S.; Cusano, R.; Uva, P.; Perra, D.; Madau, V.; Sarchioto, M.; Oppo, V.; et al. Gut Microbiota and Metabolome Alterations Associated with Parkinson's Disease. Msystems 2020, 5, e00561-20. [CrossRef] [PubMed] 